\title{
LEADERSHIP AND CONFLICT IN THE PRICING OF GASOLINE*
}

\author{
JOEL B. DIRLAM† and ALFRED E. KAHN††
}

THE petroleum industry has been plagued in recent years by unusually severe and widespread internecine battles and governmental attacks. Price wars have been frequent and of long duration. Jobber and retailer resentment of integrated refiners has become increasingly vocal and well-organized. The Department of Justice has instituted exclusive dealing suits against Standard of California, Richfield Oil, and Sun Oil and a dissolution suit against major oil companies on the Pacific Coast, while the Federal Trade Commission has conducted lengthy and violently contested proceedings, under the RobinsonPatman Act, against Standard of Indiana. ${ }^{1}$

Whether the pricing of the industry's most important product, gasoline, is "competitive" or "monopolistic" is the one element common to all of these controversies. The Department of Justice, for example, contends that the real evil of exclusive dealing is that it gives the major suppliers the power to suppress competition in retail prices. ${ }^{2}$ Similarly the FTC argues that price discrimination is monopolistic in origin and consequences. ${ }^{3}$ Actually gasoline price policies can be advanced to prove, in convincing argument, that the petroleum industry is violently competitive and in need of government intervention to restore stability; that it is a collusive or non-collusive oligopoly, acting almost exactly like a pure monopoly, which should be disintegrated; or that it is a good example of the compatibility of impure and workable

*This article issues from a study of vertical integration conducted by the writers under the auspices of the Cornell University Social Science Research Center. It was prepared with the assistance of Marshall C. Howard, now of the University of Massachusetts. The writers wish to acknowledge the extremely helpful criticisms of Ralph $\mathbf{S}$. Brown, Jr., Edwin S. Hall, J. Howard Marshall, Warren C. Platt, Eugene V. Rostow, and Myron W. Watkins.

$\dagger$ Economist, North Stonington, Connecticut.

†ंAssociate Professor of Economics, Cornell University.

1. Standard Oil Co. of California v. United States, 337 U.S. 293 (1949); United States v. Richfield Oil Corp., 99 F.Supp. 280 (1951), aff'd per curiam, 72 Sup. Ct. 665 (1952) United States v. Sun Oil Co., Civil Action No. 10483 (E.D. Pa. 1950); United States v. Standard Oil Co. of California et al., Civil Action No. 11584-C (S.D. Cal. 1950) ; Standard Oil Co. v. FTC, 340 U.S. 231 (1950); and F.T.C. Docket No. 4389 (March 24, 1952) (Modified Findings as to the Facts and Conclusion).

2. United States v. Standard Oil Co. of Cal., supra note 1, Complaint par. 62, 64; and see Lockhart \& Sacks, The Relevance of Economic Factors in Determining Whether Exclusive Arrangements Violate Section 3 of the Clayton Act, 65 HARv. L. REv. 913 (1952).

3. See F.T.C. Docket, supra note 1. 
competition, and requires no appreciable reform. This article attempts to evaluate these conflicting interpretations of the pricing of gasoline."

It is possible at the outset to reject the two extremes. Those commentators who have depicted the oil industry as a giant quasi-monopoly have over-simplified and ignored the competitive aspects of the industry-including competition in price. Yet price competition in the industry is of a special sort, to some extent insulated, sporadic, confined, at least impure. The crucial issue is whether that competition is workable-whether the industry's pricing performance is generally acceptable, in the light of the probable performance of alternative systems of industrial organization.

An additional factor makes it difficult, except perhaps in extreme cases, to arrive at sweeping condemnations or acquittals of an industry's performance. The criterion of workable, in preference to pure or perfect, competition springs from a recognition of the inevitability of market impurities and inequalities of bargaining power in the economy. The economics of workable competition therefore cannot avoid becoming, in some measure, the economics of group conflict and of individual and collective bargaining; it must investigate and appraise the interplay of group interests and power relations. And in asking whether the equilibrium of the impurities (and divergent bargaining powers) in each industry produces a socially acceptable result, ${ }^{5}$ it cannot avoid evaluating the way in which the industry reconciles the interests and apportions the fruits of economic activity among the groups it affects. Price administration is a political instrument; it determines who gets what and how much. Fairness becomes an essential criterion in judging it. $^{6}$ But what is fair by one standard or to one group may be unfair to another.

4. This study is based on a survey of the literature and trade journals, and on interviews with members of the industry and government agencies, including extended interviews in the spring of 1951 with twenty-two jolbers in a four-cuunty area, and thirty-three conventional service station dealers in a fairly large town, both in central New York state (coverage in both cases being approximately 100 per cent), conducted under the authors' supervision by Marshall C. Howard, summarized and analyzed in mimeographed reports (Sturvey of Petrolcum Joblers is Contral New York and Survey of Retail Gasoline Dealcrs) and reproduced as appendices to his unpublished dissertation, The Miarketing of Petroleual Products: A Study in the Relations ieTWEEN LARGE AND SJIALL Business (Comell University, 1951). In addition, the writers explored current marketing problems in an all-day conference with leading members of the Empire State Petroleum Association, and in interviews with executives of leading Eastern majors.

5. It is a recognition of this fact that appears to underlie Cosnsorss, Ecosionucs of COLIECTIVE ACTION (1950). See the analogous argument of Sherrard, Advarlisis:g, Product Variation, and the Limits of Econonics, $59 \mathrm{~J}$. PoL. ECow. 132, 140-2 (1951).

6. It is not implied that seciety has ever ceased to apply standards of fairness to the operation of its economy. But when one moves from a socicly in which it is generally believed that, economic power being decentralized, impersonal market forces are sufficient to assure a fair adjustment of conflicting interests, to a society in which seme concentration and inequalities of bargaining power are accepted as inevitable, the fairness of the 
In view of the often divergent goals which are set for an economic system, and of the equivocal standards of justice in the reconciliation of divergent group interests, the problem is one of achieving an acceptable balance of offsetting claims and goals, rather than selecting any one exclusively in preference to another.

\section{The Formal Pattern of Pricing}

There is no single price for gasoline. In wholesale markets there is a cargolot price to marine terminals, a tank car price to various jobbers and other customers at the refinery or at the marine or inland terminal, and a tank wagon price to retail dealers. The tank wagon price is a delivered price, (posted at the supplier's bulk plant) which dealers are supposed to pay whether they are supplied directly by refiners or indirectly through distributors. In retail markets there is a service station price to automobile drivers and a tank wagon price to commercial customers and farmers. ${ }^{7}$

The ultimate source of refined petroleum products is of course the refiner, major or independent. ${ }^{8}$ Independent refiners, who account for less than 15 per cent of the national gasoline sales, ${ }^{0}$ generally sell their gasoline either to major oil companies or to independent jobbers. Most of the latter have been spot open-market sales. The spot market is not a centralized exchange; it includes neither sales by one refiner to another, nor sales on long-term contract. Yet, while spot market transactions are only isolated, ad hoc bargains, they represent the authentic open wholesale market in the industry. And such sales have at certain times and in certain regions exercised a profound influence on the entire price structure. ${ }^{10}$

Major oil companies sell relatively little gasoline to jobbers on an openmarket, spot basis. For the most part they either distribute their gasoline directly to retail service stations and commercial accounts through their own

outcome becomes a matter of continuous public concern. Thus, while twenty or thirty years ago a businessman needed to offer no other excuse for raising his price than that the market would bear it, today most big companies feel they must justify such a performance in terms of their costs. As a result they often fail to charge as much as the traffic would bear, in marked contrast to the non-administered areas of the economy. The more imperfect the competition, the more relevant some standard of "just price." See ZWEIC, ECONOMIC IDEAS 2 (1950).

7. Some indication of the complexity of the price structure may be obtained by looking at the quotations in Platt's Oilgram (daily), National Petroleum News, The Chicago Journal of Commerce, The Gasoline Retailer, and Super-Service Station.

8. The terms "major" and "independent" are familiar in the industry, although the distinction is not precise and the boundaries between the two groups are by no means inviolate. The former are the approximately twenty vertically integrated (although seldom completely self-contained) companies, which distribute the well-advertised brands in a number of states, and account for the preponderant share of total national refinery output and sales.

9. Independent Petroleum Association of America, statistics on crude runs to stills.

10. See p. 829 infra. 
bulk plants or sell it to jobbers ${ }^{11}$ on a contract basis. The contracts, which may be for one year or more, usually guarantee distributors a margin of roughly two cents per gallon below the tank wagon price.12 Since stability is characteristic of the regular distributor's margin and since the distributor's selling price is fixed by the refiner, individual distributors have little influence on the level of gasoline prices. ${ }^{13}$

Thus the tank wagon quotation is the pivot of the formal structure of gasoline prices. Price to distributors and to commercial consumers is based on it. Majors often offer substantial (usually secret) discounts and rebates to obtain this latter business, so that, if the orders are large enough, commercial users may pay less than distributors in the same area.14 Farmers are usually charged the tank wagon price plus one cent. And, of course, retailers add a more or less conventional margin ${ }^{15}$ plus taxes to yield the price to ordinary motorists.

11. The terms employed to describe the middlemen who buy light oils (gasoline, kerosene and fuel oil) in bulk, store them, and sell in smaller quantities to retailers or consumers are not used with any consistency in the industry. Arost of these wholesalers are termed, loosely, jobbers. In central New York most of the jobbers selling (major) branded gasoline on a contractual basis (and typically handling only one brand) call themselves "distributors" (except for the few commission agents). See Howard, Survcy of Petrolenm Jobbers in Central New York, supra note 4, at 1. We shall follow this usage, reserving the term "independents" for those jobbers who sell light oils under their oun brands (often purchasing from a variety of refinery and bulk terminal sources, major

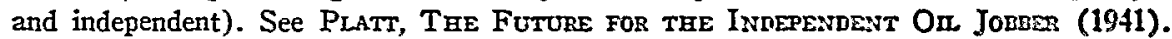

12. In the middle 1930's, jobber contracts with major refiners in midwestern marliets specified a price based on the average of the high and low mid-continent spot marliet quotations reported in the Chicago Journal of Commerce and/or Platt's Oilgram. The contracts also provided a wholly or partially guaranteed minimum margin (customarily 2 cents) even if the actual spread between spot market and tank wagon prices were less. United States v. Socony-Vacuum Oil Co., Inc., 310 U.S. 150, 193 (1940). This basic formula is still used in this area. In the Standard of Indiana market "most contracts have provided for a minimum marginal spread below Standard's nornzal tank wagon price, with the low of the spot market prevailing when to their [the jobbers'] adruntoge." National Petroleum News (October 19, 1949, p. 15) (emphasis added). In central New York the distributors pay a "distributors" price which is determined by a certain (conventional) margin below "the" tank wagon price. "The" tank wagon price is the one set by the leader, Socony-Vacuum Oil $\mathrm{C}_{0}$, and followed by other suppliers. There is no effective "spot" market in this region. When the tank wagon price changes, the price to the distributor changes by an equal amount.

13. See note 12 supra. Gasoline sold by independent jobbers, which usually carries a private brand, is frequently a major product. Prices of such "surplus" gacoline are apparently subject to considerably more bargaining than of that sold through regular channels, and exert a correspondingly more important influence on the whole price structure, at certain times.

14. See National Petroleum News, April 30, 1947, p. 5 and April 5, 1950, p.9. In a schedule of quantity discounts allowed by Standard Oil Co. of Ohio to all its commercial accounts in the state, the discount from the posted tank wagon price runs as high as 3/4 cents per gallon. Id., July 16, 1947, p.19.

15. We discuss below the determination of the retailer's margin. 
Price leadership prevails essentially at the point of fixing the tank wagon price. Historically, price leaders have reigned in each of the fairly clearly delineated multi-state market areas. There has long been a strong tendcncy for other major oil companies to follow the territorial leader in posted tank wagon prices. ${ }^{16}$ The preceding statements, which in no way prejudge the issue of how competitive gasoline pricing really is, must be qualified. First, price leadership has been a tendency only. In many cases, the so-called "leaders" have had to follow (downward) the prices of minor marketers, or other majors; and in many other cases followers have refused to follow (upward).${ }^{17}$ Secondly, such leadership as prevails is in formal posted prices

16. It is a common practice in the industry to refer to the principal marketer in each area as the leader. The statement before the TNEC of Sidney Swensrud, then Vice-President of Standard Oil Co. of Ohio, widely accepted as "the industry's" view, admits that the leader is usually the one who (a) recognizes the need for a price cut, and leads the other major refiners downward, and (b) has the responsibility for deciding when the market will stand a price increase, and so (although others will not always follow) ordinarily leads the market upward. Temporary National Economic Committec, Investigation of Concentration of Economic Power, Hearings, 76th Cong., 2d Sess. (hereinafter referred to as TNEC Hearings), pt. 15, pp. 8494, 8700-2 (1939); see also id., pt. 16, pp. 8880-1, 9221. Interviews with New York State retailers and distributors confirm the general fact of leadership, as do 2 Bain, The Economics of the Pactfic Const Petroleum Industriy 291 (1945) and Rostow, A National Policy for the Oil Industry 75-6 (1948). For reservations similar to those which we will express, see BURNs, TaE DECLINE of ConPETITION 93-109 (1936).

The "principal marketing companies" whose tank wagon prices are published by the National Petroleum News for their respective areas are the following: Atlantic Refining (Pennsylvania, southern New England, and certain south Atlantic coastal arcas), Esso Standard (New Jersey, Maryland, West Virginia, Virginia, North and South Carolina, Tennessee and Louisiana), Socony-Vacuum (New York and New England), Ohio Standard (Ohio), Indiana Standard (Indiana, Illinois, Michigan, Minnesota, Iowa, Missouri, Kansas, Nebraska, the Dakotas, and Wisconsin), Kentucky Standard (Kentucky, Alabama, Mississippi, Georgia, and Florida), The Texas Co. (Texas), Humble Oil (certain Texas cities shown also under the Texas Company), Continental Oil (far middle west), and California Standard (Pacific Coast states, Arizona, Nevada, Utah, Idaho, Hawail, and Alaska)-all but two (Texas and the main part of what went into Continental) successors to the old Standard Oil Company of New Jersey.

The 1950 announcements by leading Standard of Indiana officers that their company was renouncing its role as a price leader, while giving official recognition to a trend of many years, at the same time offered indirect corroboration of the persistence of leadership in the industry. Whether it is possible for a dominant marketer voluntarily to abdicate in this fashion remains to be seen. See pp. 836-8 infra.

17. A 1928 Federal Trade Commission report pointed out that the price-leading Standard companies did not ordinarily initiate local reductions, but detected and if necessary met price cutting by local marketers. Prices, Profits and Conspetition in tire Petroleum Industry 241 (1928) as cited in Burns, op. cit. sitpra note 16, at 102. Swensrud made the same generalization, supra note 16 . Numerous industry leaders, including Swensrud, have cited frequent instances in which the price leader "guessed wrong" in initiating an advance, was not followed, and had to retreat for fear of losing business. Sec, 
only; the resulting price uniformity is therefore in some measure illusory. Third, since leadership is far from a hard and fast, invariate practice, the crucial question emerges: how great a margin of discretion has a leader in determining his posted price? How far can he lead? Evaluation of this system of pricing is a complex problem involving subsidiary inquiries into the actual prevalence, explanation, and consequences of price leadership and uniformity. Any facile generalizations about the intensity or character of competition based on the mere existence of something called "price leadership" are therefore suspect. ${ }^{18}$

\section{The Nature and Significance of Lendership in the Tank Wagon Price}

Industry representatives maintain that price leadership is in no way incompatible with competition, and that price uniformity is the result of competition. ${ }^{19}$ The first contention rests on the general assertion that the leader has no appreciable area of discretion in fixing his price; the second on the explicit assumption of an extreme elasticity of consumer demand for any one major brand of gasoline-inter se something like purely competitive demand prevails. Thus, according to industry spokesmen, the "leader" "Ieads" only because and as long as the price which he sets is the "economic" price. He must know the market better than other marketers in order to remain "leader." The leader could not possibly "fix" or "establish" or "determine" prices at anything except competitive levels. ${ }^{20}$ If he tried, he would

e.g., testimony of W. H. Ferguson, Vice-President of Continental Oil, TNEC Hcarings, pt. 17, pp. 9400-2.

Professor Edmund P. Learned has given a detailed account of a marlet leader, Standard of Ohio, which appears to exercise very little real "leadership." Pricisg of Gasoline: A Case Study, 26 Harv. Bus. Rev. 723 (194S). Yet the general picture differs only in degree from that sketched here: Standard of Ohio can under some circumstances lead prices up, and does assume responsibility for doing so, although it is often not followed. Id. at 731, 735. It ordinarily is a follower on the downside, in the sense that it recognizes the need for openly meeting largely independent competition when the market gets out of hand. Moreover, the bulk of Learned's detailed demonstration that Standard has not been a leader is an account of the primacy of competitive forces on the refail market. This company owns and operates an exceptionally large share of the retail outlets for its gasoline. Finally, Ohio is in some degree an unusual market area, drawing upon a large number of supply sources, and a convenient place for other companies to dispose of surplus stocks without injuring their own major market areas. Id. at 727, 752.

18. Markham, The Nature and Significance of Price Leadership, 41 Ass. Eow. REv. 891 (1951).

19. See answers to questionnaire on pricing of petroleum products, submitted to 20

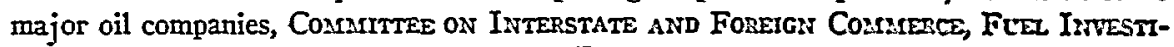
gation, Petroleum Prices and Profits, Progress Repost, H.R. Rep. No. 2342, 80th Cong., $2 d$ Sess. (1948).

20. Swensrud, TNEC Hearings, pt. 15, p. 8431 . 
not be followed, and would lose most of his customers. ${ }^{21}$ When followers follow downward, they must do so in order to meet competition. Thus, the Gulf Oil Corporation replied to a TNEC questionnaire:

"The information as to how any one or more companies arrive at prices in any particular territory is not a matter of practical concern to the Gulf Companies, because we simply have to meet the competition as we find it. We naturally sell our gasoline at the same, or somewhere near the same price at which other gasolines are sold by competitors whose products enjoy the same, or approximately the same public acceptance."22

Similarly, oil companies contend that any uniformity of wholesale gasoline prices achieved by the use of basing-points is an inevitable consequence of competition. There seems to be little doubt that Group 3, or "Tulsa plus," and the Gulf Coast bulk market have been generally used as basing-points in the past. Prices in their respective markets (midwest and east coast) were computed, regardless of the point of origin, by adding freight (rail in the first, tanker in the second) to the base spot market price. ${ }^{23}$ Major companies in their replies to the TNEC questionnaire ${ }^{24}$ denied the use of basing-points. However, they referred to the Gulf area as a "controlling market," as of course it inevitably was, and conceded their general practice of quoting f.o.b. some controlling refinery where necessary to sell in the latter's market area. They justified this in terms of the necessity of "meeting" competition as we find it," or "following the prices set by the market leaders," again in order to "meet competition." Thus, in relation to both the justification supplied by the industry and the (delivered) price uniformity which it

21. "[I]f we should maintain our prices too long when basic conditions, together with competition, required a reduction, we wouldn't be a price leader in that area very long. ... But as I see this matter of price leadership, if we reduce a price we are real leaders because we market so much of the product that the other companies have to come down to our level. If we attempt to raise a price, we are becoming less and less leaders of anything. Every time we have raised a price in the past 2 or 3 years, it has been an experiment, and I am not so happy about the results of those experiments. We frequently had to drop down and down again to the old level." Vice-President Ferguson of Continental Oil, id., pt. 17, pp. 9400-2. This statement was heavily influenced by the experience of the 1930's, when "the gasoline market has been a down-price market." Swensrud, id., pt. 15, p. 8702. A statement of the same general point of view more appropriate to the inflationary conditions of the 1940's appears in the reply of Atlantic Refining, among others, to the Fues Investigation, op. cit. supra note 19, at 18.

22. TNEC Hearings, pt. $14 \mathrm{~A}$, p. 8129.

23. See Cook, Control of the Petroleum Industry $43-4$ (TNEC Monograph 39, 1941); Review and Criticisars on Behalf of Standard Oil Co. (New Jersey) and Sun On Co. of Monograph No. 39 with Rejoinder by Monograpir Authors 49-50 (TNEC Monograph 39a, 1941). On the decline of the Group 3 base, see p. 836 infra.

24. TNEC Hearings, pt. 14A, pp. 8123-45. 
yields, basing-point pricing is merely ancillary to price leadership. Both are explained as not only compatible with but required by competition.

The logic of the oil industry's rationalization of its wholesale pricing practices is the logic of pure competition. Price is determined by the impersonal forces of the market and must be accepted by all sellers. Leadership is merely a process of finding that price.

But if oil companies are in business to make profits as high, in the long run, as the market will bear, can such an oligopoly produce the same price results as more atomistic competition? Most geographic market areas are dominated by a relatively small number of large companies, ${ }^{25}$ with a fringe of independents. The majors compete in the sale of an essentially standardized product. ${ }^{26}$ The product of the independents, where available, enjoys less consumer acceptance, ordinarily finds a market niche at a price differential, and does not, perhaps in most cases, disrupt the pattern of leadership. Markets thus dominated are certainly less likely than purer markets to be characterized by vigorous, continusous and overt price competition. ${ }^{27}$

The price leader probably cannot maintain a price increase if competitors do not follow. The real question, then, is whether competitors will and do follow-up to the point at which industry profits are maximized. Assuming no divergence of opinion among the majors about the location of that point, and assuming a continued willingness of all (including independents) to forego price rivalry as a means of attempting to increase their shares in the market and in those total profits-both admittedly crucial assumptionsthey surely will follow. The latter portion of the Gulf Oil Corporation's explanation of its policy of following the leader, reproduced above, indicates that, to some extent, they do follow and forego price rivalry:

"We naturally sell our gasoline at the same, or somewhere near the same price at which other gasolines are sold by competitors whose

25. TNEC studies established the modal number at eleven. Cook, op. cit. sujpra note 23 , at 41 . Concentration within the eleven is fairly marked, with effective market leadership in substantially fewer hands. On the other hand, the fact that eleven is "fev" by no means answers the question whether it is too few, or unusually few. See pp. $827-8,344-5 \mathrm{infra}$.

26. Oil companies of course attempt to differentiate their gasoline by additives, coloration, and advertising, and by continuous research in refining techniques to produce superior fuels. The fact remains, as they themselves constantly stress in arguing the inevitability of price uniformity, that these nationally advertised brands are sufficiently uniform in quality to have almost equal consumer acceptance, so that no one could long sell for an appreciably higher price than another.

27. We do not necessarily imply that price competition of this sort is the only socially acceptable kind, that it is feasible in the oil industry, or that some other system of organization is available which will yield a socially more acceptable composite competitive performance. Our point is, simply, that it is unconvincing for the oil companies to argue that their industry is typically characterized by dynamic price rivalry. 
products enjoy the same ... public acceptance. It would be impossible to sell at a higher price, and, on the contrary, self-intercst usually prevents our selling at a lower price."28

To fail to follow is to forego profits. Any gain in volume can only be temporary, because the leader will have to come back down. Under the above-listed assumptions, the Gulf statement may be paraphrased: "Self-interest precludes price competition and dictates acceptance of the price which the market leader estimates will maximize total industry profits." The resulting price contains some monopolistic element. ${ }^{29}$

Whether the price is seriously exploitative depends on how far the oil companies are willing and able to march in step; how far, conversely, divergences of opinion and interest will permit the leader to go. One major may desire to invade another's market, or to make fuller use of capacity. A good margin may tempt independents and majors, other than the leader, to cut price in order to increase volume. Implicit competitive influences of this sort may place very narrow limits upon the discretion of the leader, even though overt price warfare is sporadic.

Patterns of leadership have often been upset by differences of opinion about whether "the market" would take a price rise, and by the price concessions of majors or independents. However, oil company executives recognize explicitly that price rivalry is dangerous (as indeed it is); that because of the high cross-elasticity of demand between major brands, price cuts are "not an effective means of gaining gallonage"; $;$ and that following the leaders' posted prices on branded gasolines, up as well as down, is the wisest policy.

What then of the "impersonal forces of the market" which are, instead, supposed to fix gasoline prices? It is sufficient to say that the industry demand curve seems sufficiently inelastic, within a broad range, to provide room for different prices capable of equating supply and demand, depending on the policies of the suppliers. ${ }^{31}$ The crucial determinant is the factor of supply.

28. TNEC Hearings, supra note 21 (emphasis added). The Sun Oil Co.'s reply to a Congressional Committee questionnaire (FuEL INVESTIGATION, op. cit. supra note 19, at 15) was much the same: to charge less than the posted price is to take less revenute than is obtainable, and also will probably make it difficult to supply one's regular customers, because of the resultant increase in demand.

29. Cf. Swensrud: "Price leadership does not mean that the price leader can set prices to get the maximum profit and force the other marketers to conform." TNEC Hearings, pt. 15, p. 8702. Again, "When, however, everybody is feeling the pressures for an increase, and some responsible marketer finally takes the initiative and announces an increase, other companies ordinarily are very glad to follow very promptly." ConGREssional INTEREST IN THE OIL INDUSTRY 5 (1948). It should be clear that such statements are not incompatible with the hypothesis in the body of the text. The leader does not have to be able to force a small number of sellers into a non-competitive price.

30. Review and Criticisms, op. cit. stipra note 23, at 46 .

31. Ibid. 


\section{The Threat of Price Competition and the Scarch for Stability}

On the supply side a number of factors persistently threaten the stability of the gasoline market and explain both the quest for stability and its incomplete attainment. First, conditions of production in this industry make supply difficult to limit. Major producers have an immense investment in crude oil facilities, pipe lines, refineries, bulk plant facilities, tankers, and marketing outlets (including a species of investment in the good will of thousands of distributors and dealers). These heavy fixed costs give rise to a correspondingly severe pressure to maintain and increase gallonage. Refining is a continuous process, which, following a stoppage, is extremely costly to restart.32 However individual units are closed periodically for cleaning or repairs. And they may be shut down because of obsolescence, or for lack of either supply of crude or demand for refined products. But ordinarily refineries operate at capacity and sell the product when and as best they can. ${ }^{33}$ In the absence of government controls, and under the rule of capture, ${ }^{34}$ pressure would be irresistible to extract crude oil from the ground far more rapidly than is now being done. And, at the other end, there is excess capacity in marketing in the sense that unit costs would decline and profits would respond far more than proportionately, within very wide limits, to any increase in physical volume. In all cases, therefore, there is strong pressure to produce and distribute through whatever channels can be found.

Second, eleven major sellers ${ }^{35}$ do not behave as one. And it may reasonably be asked whether eleven sellers represent an unusually limited number of alternatives, except in contrast with theoretically pure competition. In this burgeoning industry, which every year attains new output records, producers are extremely individualistic. Profits are continually plowed bacli into exploration and expansion of refining and marketing facilities. ${ }^{30}$ Despite a general recognition that open price cutting is a futile method of altering the division of markets and profits to one's advantage, there is no simple disposition to accept the status quo. Most of the successor companies of the

32. See Marshall, Book Review, 57 Yale L. J. 1323 (1948).

33. It is not possible to determine, from the published Bureau of Mines statisties, the extent to which unused capacity could correctly be classified as excess. See Arensicns: Petroleuns Institute, Petroleuns Facts and Figudes $2 \$ 6$ (1950). In 1933 and 1934, cracking plants appeared to be operating at about 80 per cent of capacity, but since 1935 cracking capacity seems to have been utilized at over 90 per cent of capacity. BukEnu of Mines, Inforasation Circular No. 7578 (August, 1950). According to chemical engineers, operation at 95 per cent of capacity is the masimum that can be expected.

34. Under the rule of capture, the gorerning legal principle, a landorner has title to the oil under the surface only to the extent that he takes it out See MICDougaL $\&$ Haber, Property, Wealth and LaNd 201-S (194S).

35. See Coor, op. cit. stipra note 23.

36. See Fuel Investigation, op. cit. stpra note 19, at 3-6, 9-14; Pogue \& Conueron; Capital Foraration in the Petroleuar Industry (Amer. Inst. of Mining and Metallurgical Engineers, Tech. Publ. No. 2431, Sept. 1948). 
Standard Oil Trust, for example, have expanded their operations geographically and vertically, sometimes in strenuous competition with one another, and a roughly equal number of aggressive newer giants have appeared on the scene. ${ }^{37}$ These competitive activities, similarly, carry a powerful threat of disrupting price structures.

Moreover, at all stages of the industry there are independents, frequently less scrupulous than the majors about price cutting. Because many of them do not enjoy the benefits of a nationally-advertised brand, they must in many cases rely on price competition-shopping for bargains and selling below the majors-to stay in business. To some extent they complement each other: the truly independent retail service stations, owned by the dealer himself, or the independent jobber often purchase their gasoline from smaller refiners, - and the latter their crude oil from independent producers. But independent jobbers are largely supplied by majors, often on a discriminatory or preferential basis, taking advantage of the big companies' rivalry for gallonage, or attempts to invade a new market. ${ }^{38}$

However, these competitive influences counsel moderation in rivalry. They suggest the necessity for a stable official price structure, within which an orderly, though earnest, competition may thrive. When the giants do engage in something like open price rivalry among themselves (which they apparently rarely initiate), competition produces not a stable equilibrium but a cumulative, chain-reaction price war. Such price wars may be succeeded by a truce only after a period of years, during which returns in the affected areas have probably fallen below average cost. Because of the constant threat of severe and destructive price competition majors try to avoid direct and open price rivalry. Whether an economist would agree that such avoidance is necessary or socially desirable depends very much on the economist. Many would doubtless admit the possibility of truly destructive competition under the conditions of the 1930 s. But with demand during the past 12 years constantly expanding and threatening to outstrip supply, there is at least more room for doubt that open price competition is inherently destructive or could keep prices below average costs for very long. In any event, all members of the industry feel the need "to build a wall of insulation against the white heat of so-called free competition." 39

37. See Burns, op. cit. supra note 16, at 100-5, 423 .

38. On the greater price aggressiveness of independent suppliers and marketers, and the way in which they can, in some circumstances, precipitate continuous and violent price competition, see Cassady \& Jones, The Nature of Competition in Gasoline DistruBution at the Retail Level 79-92, 107, 122-38, 213-4 (1951).

39. John Dressler, President of the New Jersey Gasoline Retailers Association, as reported in The Gasoline Retailer, March 7, 1950, p. 10. Mr. Dressler, who has often criticized the major companies, is not in this statement extolling "the white heat of socalled free competition," but merely arguing that small as well as big business needs some kind of insulation from it. 
In the search for a stable price structure attempts have been made to control supply at the source. Support of the state and federal governments was readily enlisted, even before 1930, when wasteful exploitation of newly discovered flush fields made obvious the need for control of crude production in the interest of conservation. Under the system of prorationing which emerged, Bureau of Mines estimates of national demand for petroleum products are translated into individual state, and finally into individual well production quotas. It is not necessary in this study to evaluate these programs in detail-except to note that they have undoubtedly tended to restrict supply. 40

In the 1930's, when state production control proved insufficient to check the flow of Texas and mid-continent crude, several major oil companies, in order to support spot tank car prices, engaged in joint collusive programs of purchasing "distress" gasoline sold in the mid-western areas by independent refiners. Since spot price, when sufficiently low, both governed the price to the major companies' distributors, and represented the price at which independent jobbers had access to gasoline, its control was essential to the support of the entire regional price structure. ${ }^{11}$

Several additional charges of collusion by major oil companies with respect to supply and price have been filed by the Department of Justice. Allegations of similar joint buying programs, and of offers of direct inducements to independent refiners to restrict output, were made in a criminal case under the Sherman Act against all the major and secondary oil companies, two trade associations, and the majority of independents in the Pacific Coast area. ${ }^{42}$ The defendants pleaded nolo contendere and paid fines. In other cases, as yet undecided, the government makes far more sweeping charges of collusive pricing in the industry. ${ }^{43}$ In addition, the state of Texas has recently filed a similar complaint against ten major oil marketing companies, purportedly accounting for about 80 per cent of the gasoline business in the state. Among other alleged collective efforts to control price, the complaint charges that tank wagon price increases have been "practically simultaneous,"

40. See Till, Gasoline-The Competition of Big Business in Hasmiton, Prrce Asd Price Poltctes $\$ 4$ (1938); Watkrns, Oil: Stabilization on Consenvitioz? (1937); TNEC Hearings, pt. 17, pp. 9584-9603; OII Supply and Distanumion Problears, H.R. REP. No. 25, 81st Cong., 1st Sess. $13-19$ (1949); Oxenfelrt, Industrual Pruct:ic aidd MIARKET Practices 434-43 (1951).

41. See note 12 supra; United States v. Socony-Vacuum Oil Co., Inc., 310 U.S. 150 (1940).

42. United States v. General Petroleum Corp. of Cal., Cr. 14149, S.D. Cal., 1939; 2 BAIN, op. cit. supra note 16, at 270-S5.

43. United States v. American Petroleum Institute, Civil No. 8524, D. Col., 1940. This case was suspended for the duration of World War II and permanently withdrawn in June, 1951. In M1ay of 1950, the Department of Justice instituted one regionalized substitute for the 1940 "Mother Hubbard" case, in bringing similar omnibus charges against major oil companies in California. United States v. Standard Oil Co., of Cal., Civil No. 11584-C, S.D. Cal., May 12, 1950. 
and that "in making any change in tank-wagon gasoline prices, each defendant did so with the knowledge that each of the other defendants had done or would do likewise." 44

As this study is not concerned with issues of guilt or innocence at law, it seems sufficient to conclude that "the natural forces of demand and supply" are restricted by a more or less consistent forbearance from open competition in the posted tank wagon price. Supply is not an objective datum. It depends on company policies. Price leadership in itself implies a limitation on supply: an unwillingness to offer more for sale, at least openly, through regular outlets, than can be absorbed at the leader's price. The majors, at least, direct their pricing policy toward retaining rather than increasing pre-existing market shares. One can no more escape remarking on their forbearance from rivalry in the tank wagon price than failing to understand how ridiculous it would be to expect them to compete actively in such fashion.

Supply in the oil industry depends also on government policy. With a partially effective price leadership superimposed on a system of prorationing which restricts output of the basic raw material to an estimate of what the market will absorb at current prices, it becomes impossible seriously to maintain that the industry is competitive in the sense that each producer individually expands output as long as market price exceeds cost. It does not necessarily follow that monopoly profits are being earned in petroleum refining. In fact oil company profits are apparently no higher than the national average for manufacturing. ${ }^{45}$ But it does follow that the mere fact that "you

44. Plaintiff's First Amended Original Petition, State of Texas v. Arkansas Fuel Oil Co., No. 82,980, Dist. Ct. of Travis County, Texas 98th Judicial Dist., Aug. 1950.

45. According to the reports of the National City Bank, petroleum companies' earnings have been slightly below the average of manufacturing companies in the last 20 years; averages of the annual rates of return (after taxes, as per cent of net worth) were roughly $4.2,8.4$, and $15.2 \%$, in the periods $1931-40,1941-5$ and $1945-50$ for the former, and 6.1, 10.1, and 15.8 respectively, for all manufacturing companies. It is possible for an industry to be characterized by monopolistic competition without earning monopoly profits; if entry into the field is sufficiently easy, the only chief uneconomic consequence of the monopoly elements may be an excess of capacity.

The above profit figures are not underestimated on account of the controversial $271 / 2$ per cent depletion allowance. Oil companies use the percentage depletion only for income tax purposes. In reports to stockholders and the S.E.C., depletion is determined almost uniformly on a cost basis (the depletion cost per barrel produced being determined by dividing total exploratory and developmental expenses by estimated reserves). Morcover, since the above figures are for profits after taxes, they are already magnified by the favorable tax treatment. See testimony of Randolph Paul in Hearings before Committec on Ways and Means on Revenue Revision of 1942, 77th Cong., 2d Sess. 2996 (1942). These statements are corroborated by a letter from Joseph A. Pogue to the authors, and by some company reports in Moody's Industrials. See also Stocker, Percentage Depletron of OIL aNd Gas Properties (unpublished thesis in Cornell University Library, 1950).

Profits may be underestimated for a different reason. Internal Revenue regulations permit producing companies either to capitalize or to charge directly to revenue certain 
can't defy the law of supply and demand," as oil industry executives frequently aver, in no way vitiates the conclusion that there is a good deal of arbitrariness in the market price of gasoline.

\section{The Persistence of Competition}

Within this pricing framework, and often disrupting it, competition for additional gasoline sales persists. It assumes four distinct shapes: (1) nonprice competition, (2) indirect price competition, (3) discriminatory pricing, notably in the disposal of "surplus" gasoline, and (4) periodic retail level price wars which (though probably seldom consciously instigated by suppliers, are often none the less attributable in part to their policies) usually force intense competition upon suppliers.

Non-price competition involves rivalry in advertising, service, and in the development of superior fuels and lubricants. It need not detain us in a discussion of pricing policy, because it is the one of the four which is truly "nonprice"-although, of course, giving the customer more for his money, or making him think you are, is a kind of price competition too. An obvious and important case in point is the Sun Oil Company's policy of offering higher than standard octane gasoline at standard prices.

Indirect price competition, in contrast, really is a species of departure from the posted price. When oil refiners or marketers obtain the patronage of retail outlets by making improvements of the latter's grounds and buildings, paving driveways, painting garages free of charge, or by making loans or gifts of tanks, pumps, or compressors, they are really competing in price. The same is true when they offer varying preferential rental agreements. That such indirect price concessions are in a sense competitive is clearly indicated by the current complaints of jobber associations aimed both at major oil companies and competing jobbers, who take away customers in this way. ${ }^{10}$

developmental and exploratory expenses. The practice is apparently widespread of using the second alternative, even in reporting to stockholders, for exploration which has eventuated in dry holes. Since producing companies do not capitalize a portion of exploratory expenses, which might legitimately be considered part of the cost of acquiring producing wells (as the Treasury Department has recommended they be required to do-sce testimony of Randolph Paul, Hearings, supra, at 2988, 2996-\$), the result is, in the year expenses are incurred, to show a net income (and net worth) lower by this amount. Hence the apparent rate of return appears to be reduced. If such expenses have increased over the years, a persistently lower rate of return is shown than would appear if all exploratory expenses were capitalized and amortized annually.

The authors lack sufficient information to appraise this qualification of the published profits data. However, any resultant understatement of earnings applies only to the producing branch of the industry, which (see note 108 infra) is the most profitable one; and it appears to be a relatively small factor in the total profits of the integrated companics. Substantial tax savings from including such expenditures and applying percentage depletion are already manifest in the profit figures.

46. One independent wholesaler complained in an interview that he was in constant danger of losing his outlets because he could not afford to provide black-top driveways 
Jobbers complain, for example, that major companies often manipulate their rentals in order to get business, thus in effect taking a lower return on their real estate operations in order to sell gasoline. A dealer who owns his station may lease it to a major and then lease it back on more favorable, possibly nominal, terms. A dealer who pays a station rental of 1 cent per gallon is really paying less for his gasoline than the dealer who pays $11 / 2$ cents per gallon, if the service stations are equally desirable. Because stations differ, it is difficult to prove such de facto price cutting, but for the same reason the situation is manifestly conducive to these competitive tactics.

Indirect price competition is attractive to the major companies for two reasons. First, it does not disturb the uniform nominal wholesale price structure, and thus is not incompatible with "orderly" competition. Second, like many forms of non-price competition, it is expensive, and so favors the large, wealthy firm, which alone can make such heavy "investments" to take the business away from the independent jobber or the tied distributor. It is for this reason that smaller competitors often consider such tactics "unfair" and indignantly demand their cessation. ${ }^{47}$

The next important manifestation of competition is price discrimination. A major refiner attempting to invade a new territory may shade his prices to obtain distributors; a major supplier or an aggressive distributor may offer

gratis. The majors had no scruples about using such inducements to get supply contracts. Significantly, the N.R.A. Code for the petroleum industry contained numerous and elaborate provisions for preventing all such forms of competition. WATkINs, op. cil. supra note 40 , at $170-3$.

On the other hand, this form of competition, like the others described in this scction, does not ordinarily result in lower prices to the consumer. It represents instead a method, often unsuccessful, of channeling rivalry in such a way as not to upset the price structure.

Allegedly discriminatory rental agreements, offered in order to induce exclusive dcaling, were the subject of a recent treble damage suit. Myers ct al. v. Shell Oil Co. ct al., 96 F. Supp. 670 (S.D. Cal. 1951). The Court held the complaint had failed to show a good cause of action.

47. "We are thoroughly disgusted with a few major oil companies today, In fact we are just plain good and mad! There are a few of these weight throwers around these parts, who insist on buying their volume through these $1 / 2$ cent renewal agreements with the other fellow's dealers. They don't seem capable of going out and acquiring volume the way the jobber has to do-on the strength of better service, and better products. They have to buy it. ... When you approach them on a specific case, they will tell you that another major has been digging into their volume by granting special deals, and that they therefore have no choice but to do the same. Most of the time they are right. Other majors are buying their volume. It is a vicious circle. . . A few of the more greedy gobblers are causing the national small business kettle of resentment to boil against all big business. Let's face a couple of truths: Either the price of gasoline is too high, or these few majors are guilty of using integrated earnings to subsidize marketing losses. It's a lead pipe cinch that they aren't operating any cheaper or more efficiently than the average local jobber is, and if each divisional office of every major company had to show a profit on its marketing earnings, they wouldn't be able to afford the luxuries of giving their profits away in order to 'look good' at the home office." Northwest Petroleun Association, Bulletin No. 528 (September 1, 1950). 
secret concessions to big commercial customers or dealers; many refiners sell tank-cars of "surplus" gasoline to independent jobbers for resale sometimes under the major brand, sometimes under a private brand, below posted prices. This "surplus" may indeed be a temporary excess of supply over demand; however, for many majors it is simply that portion of the normal supply which, as a long-range practice, they distribute through other than their formally recognized channels. Secrecy or separation of customers is usually sought in order to limit the effects of these actions. Many of the multi-pump stations (large volume stations, with numerous pumps but usually handling only a single brand) which have recently made their appearance on the west and east coasts sell their gasoline under private brand names, even though much of their supplies come from major oil companies. Removal of the national brand name apparently has the purpose of carefully channeling this gasoline without upsetting the entire market.18 Major gasoline is sometimes sold at cut rates to independent wholesaler-retailers through brokers in order to conceal its origin.

Nevertheless, these drives for additional gallonage frequently upset the market. They cannot fail to affront some competitor. If provocation either by the competing supplier or by the favored customer is sufficiently great, retaliation and price wars such as have abounded since 1949, may result.49 At such times, the posted tank wagon prices often become entirely fictional; but the fiction may be retained for a long time. Suppliers, anxious to keep their dealers in business, have commonly granted rebates from the posted price (usually covering only part of the required retail price reduction) in order to permit the required reduction at the retail level. ${ }^{20}$ Where major oil companies distribute through jobbers, they have frequently made the latter

48. See Wolnstadt, Multipuxip Service Statrons, Today asd Tossorson (1950). When the national brand is removed, the discount from the tanls wagon price is not discriminatory, strictly speaking, and in some ways not competitive (see note 46 supra), since a different and inferior product in the economic sense is being sold.

49. In the Standard of Indiana case (supra note 1), the F.T.C. atttributed the instability of the Detroit market in the late 1930's to Standard's concession of the tanls car price to four jobbers, some of whom in turn undercut the going tank wagon and retail prices. See also the excellent case study of a similarly upset market in CASSADY \& Jo:iES, op. cit. supra note 38 .

50. In the $1950 \mathrm{St}$. Louis price wars, for example, suppliers billed their dealers at the posted tank wagon price, with a "temporary rebate" indicated at the bottom of the invoice. See The Gasoline Retailer, May 10, 1950, p.2. For discussion of rebates in the 1950 New Jersey price war, see The Oil Marketer, November 20, 1950, p. 4; the rebates in the California price war are discussed in National Petroleum News, July 5, 1950, p.15; see also S. B. Eckert, Executive Vice-President, Sun Oil Company, What Aboust "Gassline Price Wars?," Sunoco Diamond, October, 1950, p.12; and Report of the Governor's Committee to Investigate the Gasoline Price War, Hartford, Conn., December 23, 1950, p.7.

According to id. at 9, the 5 cent drop in retail prices in Connecticut was borne, roughly. 1.5 cents by the retailer, 1 cent by the wholesaler, and 2.5 cents by the major supplier. See also CASSAdY \& JonEs, op. cit. supra note 38 , at 152. 
share the cost of the subsidy. ${ }^{51}$ Apparently this form of subsidy is a postwar phenomenon; for according to the Executive Secretary of the Serve Yourself Gasoline Stations Association (California), in reference to a Los Angeles region price war, "Never before in history has the tank wagon price failed to drop with retail prices." On Only after more than a year of frequently devastating price wars in the northeast were posted prices openly reduced. The Sun Oil. Company justified the reduction on the ground that universal rebating had made the posted prices unrealistic; and the Atlantic Company, Pennsylvania's market leader, on reducing posted price, simultaneously announced the withdrawal of its previous "price support" to dealers in the Philadelphia area. ${ }^{53}$

Such subsidies are of course a form of price competition at the wholesale level. As soon as one supplier goes to the aid of his retail outlets, others find it necessary to follow. Subsidies have the advantage over outright reductions in posted prices of being selective, clearly temporary, and defensive in character, thus providing an excuse to return to the former level as soon as the price war has abated. The undisturbed structure of posted prices provides a comforting assurance that when the warriors have had enough, the beacon is still there to direct them home.

\section{Price Policy of Indiana Standard-A Case Study}

An examination of the pricing practices of a particular major oil company provides a specific illustration of what has up to this point been described in relatively general terms. Standard Oil Company (Indiana) has generally been known as the market leader in the great midwestern market area. This is a huge market, upon which converge the crude and refined oil products of the mid-continent and Gulf Coast, the Michigan-Illinois, and the Wyoming-Montana fields, carried by a network of waterway, rail and pipe line facilities.

Standard's reply to the TNEC questionnaire in 1939 provides its own version of its pricing policy up to that year. ${ }^{54}$ The general picture conveyed

51. In the $1950 \mathrm{St}$. Louis price wars the major company suppliers were giving a 0.9 cent per gallon rebate to those of their jobbers who would give a 1.8 cent rebate to their service stations. This policy apparently made things quite difficult for those jobbers who had already been granting their dealers a secret concession of 1 cent to get their business. The Gasoline Retailer, May 10, 1950, p. 2.

52. National Petroleum News, July 5, 1950, p. 15; Cassady \& Jones, op. cit. supra note 38 , at 151 .

53. N.Y. Herald Tribune, May 25, 1951, p. 27, col. 8. In announcing a second price cut in this area, Atlantic again made it clear that these were to be "net prices." Sun, instead, apparently continued to give rebates. Empire State Petroleum Ass'n, Weekly Letter, June 22, 1951.

54. "Refineries are located with certain existing and anticipated economic factors definitely in mind, including transportation costs of both crude and finished products. During the operating life of a refinery those economic factors change very rapidly. During 
by this statement seems to be that of a dominant seller at first pricing more or less independently of others (and presumably followed by them), gradually losing its predominant position (between 1928 and 1940 Indiana Standard's percentage of total sales in its market area dropped from $34 \% 0$ to $20 \% 0$ ), then quoting in different markets f.o.b. the dominant refinery (sometimes its own, sometimes that of a competitor), and finally-after a period of some

the early years of the company's existence, when competition was not severe, its normal prices were based upon an established price at each supplying refinery, plus freight to point of distribution. As competition increased and products were marlieted by others from a variety of sources, it became necessary for the company, in order to meet such competition and to keep its prices uniform and orderly, to consider each state as a separate competitive area and establish a base price at each supplying refinery for each such state, which would result in a competitive price in the field. In instances when products were shipped from a refinery not normally supplying an area, the freight rate from and the base price at the refinery customarily used for supplying purposes was considered as the basis for price purposes. These instances or exceptions became vastly more numerous with the growth in competition and the rapid change in other economic fastors surrounding each refinery. The foregoing method was substantially the system in use prior to the latter part of 1934. Prior to the 1934 change just referred to, economic factors had come into being to an extent and in a variety of means not previously experienced: vast crude discoveries, hot oil, the N.I.R.A., and tremendous growth of competition of every form. Again, and for the purpose of attempting to place the company's normal prices in line with such competition and keep said prices orderly and uniform, the company adopted a method of establishing a base price at Group 3, which was composed of the average published tank car price plus a spread and which, when added to the freight from Group 3, would total the price previously determined to be necessary in the field. Group 3 was selected because freight from that point represented the one element that was common in the price of neariy all competitive gasoline, and it was these competitive gasoline prices that the company was obliged to meet. Subject to one mudification, this is the current method. The modification referred to is this: when the company first established the Group 3 method for its normal tank wagon prices, such normal prices were permitted to fluctuate with the published spot tank"car markets in Group 3. This automatic fluctuation has long since been abandoned and the company's current normal price basis in no respect bears any fixed relationship to the spot tank car market in Group 3 or elsewhere.

"Obviously, when a like product is being sold at a large number of points and in active competition with comparable products supplied by others, the company must have some orderly method of keeping its prices between adjacent localities approximately uniform and level, and at the same time approximately level with the average competitive prices. Indeed, uniformity of the company's own prices is required by the laws of most states." TNEC Hearings, pt. 14A, p. $\$ 133$ (emphasis added),

With respect to the company's less important Wyoming refineries, it said: "No attempt is made to establish a normal price structure, but rather the company follows from time to time the prices established by the company having the largest or most complete distribution or local competition established by anyone having sufficient volume to affect the company's business."

55. Robert E. Wilson, Chairman of the Board, Standard Oil Company (Indiana), Oil Competition in the Midwost-Case History. reprint of address presented at the 47th Semi-annual Meeting of the National Petroleum Association, Cleveland, Ohio, April 30, 1950, p. 16. 
confusion and the entrance of new competitive influences-settling on a single basing-point formula for the entire area.

There have apparently been two important changes in the latter policy in recent years-the disintegration of the single basing-point system and some relinquishment of price leadership. In September 1949 Standard announced the abandonment of Group 3 as the basis for its tank wagon prices throughout its 11 state market leadership area. ${ }^{56}$ The National Petroleum News reported the factors impelling this change-scores of actual and potential pricing points had developed due to the use of water transportation up the Mississippi, Illinois, Ohio, and Missouri Rivers, the building of terminals along these rivers, the growth of product pipe lines, and the erection of new refineries in the midwest ${ }^{57}$-and implied that the disintegration of Group 3 had been a gradual development:

"We still do not understand why the Standard of Indiana made any announcement of the change because obviously it had been meeting competition as it found it from many refineries, barge terminal and pipe line points, all of which had knocked Group 3 plus rail freight as a tank wagon price basis into a cocked hat years ago."

In April 1950 Robert E. Wilson, Chairman of the Board of Standard Oil Co. (Indiana) stated:

"We have decided we would prefer to be known as a leading marketer and take no overall responsibility for being the first or last to 'recognize current conditions." "59

Three months later, Thomas E. Sunderland, the company's general counsel, explained that his company had been forced to discontinue public announcements of price changes "for legal reasons":

"The trend in court decisions had been such that the government agencies were sustained in claiming that a public announcement of a price change could be construed legally as the equivalent of an 'invitation' to a company's competitors to follow the price change. If a competitor subsequently did follow such a price change, it was then possible for the government to claim, and the courts tended to support the claim, that this completed a 'price conspiracy' between the two competitors and a violation of the federal antitrust laws. ... It is and

56. National Petroleum News, Sept. 14, 1949, p. 13; Dec. 28, 1949, p. 15.

57. Id., Sept. 21, 1949, p. 23.

58. Id., Dec. 28,1949, p. 15. As a result of these cheaper forms of transportation, the average price spread between Tulsa and the Twin Cities in the period 1948-50 was 2.18 cents per gallon, compared with a rail rate of 3.63 cents. John W. Boatwright, Vertical Integration in the Petroleum Industry, address before the Univ. of Illinois symposium on vertical integration, Oct. 27, 1951, p. 13.

59. Address by Robert E. Wilson, supra note 55, at 22 . 
will continue to be the policy of Standard to post its local prices at each bulk plant or other supply point. This is required in many states by the law of that state."

Some observers expressed the concern that the new policy would create difficulties for the jobber. Since the "normal" tank wagon price has heretofore been used as a peg on which to hang the jobber's margin, the disappearance of an openly announced, normal price, it was feared, might jeopardize the stable and uniform margin. ${ }^{61}$ Others predicted a weakening of the price leadership system:

"It would appear that there will be no general market leader, instead there will be a market leader for various local areas. This market leader might be an independent, a trackside operator or a cooperative, as well as Indiana Standard. This was bound to come because there has been too much of a range in transportation costs. Group 3 has been obsolete for too long." 62

However, still others suggested that Standard's new freedom of action might bring greater rather than less price stability. Previously, as price leader (paradoxically), it had been the last of the major oil companies to reduce prices in a local price war, thus offering some incentive to price-cutters. Now, it apparently feels freer rapidly to meet local price competition. It was said to be the first to reduce prices in a 1949 Madison, Wisconsin price war in order to protect its gallonage. ${ }^{63}$ This new tactic by Standard, it has been predicted, may tend to discourage local price-cutting. Thus relaxation of price leadership may result in steadier prices and less shading.

Standard may not be able to abdicate its role of "reference seller" or "market leader." One of its bulk agents is said to have posted the prices on the ceiling of his office, telling inquiring visitors that the step ladder was in the back room. ${ }^{64}$ In any case, its prices are still available to the public in trade journals. ${ }^{65}$ And refiners and jobbers in the area may feel they have to find some new stable pricing system which will not be disruptive and which will yield a "constant price pattern."

60. National Petroleum News, July 19, 1950, p.20.

61. See id., September 14, 1949, p. 14.

62. Ibid. (reporting the Secretary of the South Dakota Independent Oil Mren's Association).

63. Id., October 19, 1949, p. 15.

64. Id., September 14, 1949, p. 14.

65. The National Petroleum News now remarks under Indiana Standard's prices: "Tank wagon prices listed below were obtained by NPN correspondents who visited Standard of Indiana bulk plants where the company's prices are publicly posted."

66. See National Petroleum News, October 5, 1949, p. 5: "Plans are known to have been discussed at some oil company board meetings as how best to devise some constant price pattern-subject only to the usual local variations-in mid-western areas in which 
refineries as basing-points, and Standard's prices as reference price. This is particularly true if Standard follows the practice of quickly meeting local competition, avoids quoting prices which yield too high a profit margin, and, thus, on both counts, discourages potential competitors. ${ }^{67}$

It is difficult to supply a simple economic evaluation of these changes (actual and prospective) in the wholesale pricing of gasoline in Standard's areas. Lower margins dictated by new (and potential) competition and less rigid pricing would appear to be in the public interest. At the same time, greater flexibility in meeting local price cutting may have the effect of holding the price line. This is the familiar dilemma of evaluating "meeting competitors' prices" in oligopolistic markets.

\section{Determinatron of the Retail Margin and Price}

The posted tank wagon price of the majors is the keystone of gasoline price structure. Since today's major suppliers apparently operate less than five per cent of the service stations, ${ }^{68}$ they cannot formally control retail price. ${ }^{00}$ It is necessary therefore to shift the focus of the discussion, in order to appraise the degree of autonomy possessed by the retailer, and to explore factors influencing both the size of the retail margin and the retail price.

Entry into gasoline retailing is relatively easy. Major companies, in their quest for maximum exclusive-dealer representation in each area, directly and indirectly encourage the multiplication of service stations. Through their leasing arrangements, they facilitate entry for a man who promises to be a

Standard Oil (Indiana) markets. One company says it is studying carefully the possibility of a formula using certain of Standard's refinery locations as basing-points in developing a system of competitive prices. Thus, it was pointed out, Standard's refineries, instead of Group 3, might well serve the industry in lieu of any other pricing method, should others adopt the same idea."

67. Standard is well aware of the danger of maintaining wide profit margins. Robert $\mathrm{E}$. Wilson has described the company's previous pricing policy as giving competitors "a wide open opportunity to land on our beaches and dig themselves in." Address. supra note 55 , at 20 .

68. This, the percentage in California (see United States v. Standard Oil Co. of California, supra note 43 , Complaint par. 61 ) is probably near or below the national average. See Fuel Investigation, op. cit. supra note 19, answers to question 13; Swensrud, TNEC Hearings, pt. 15, p. 8416.

69. This has not always been the case. "Prior to 1935 , suppliers generally assumed the responsibility for establishing posted retail prices." Id. at p. 8698. On their failure to make use of resale price maintenance, see pp. 839-40.

- According to Howard, Survey of Retail Gasoline Dealers, supra note 4, at 8-11, the suppliers' "suggested" price was regularly followed. No coercion to this end was reported, although those dealers who leased (typically with a 30 day cancellation clause) might well have been subject to pressure. Compare statement of Richfield in answer to questionnaire of Fued Investigation, op. cit. supra note 19, at 56: "The Company does not control filling or service stations," with argument of its attorney before U.S. Supreme Court, 20 U.S.L. WeEk 3261-3 (U.S. April 8, 1952). 
competent representative, even though his own financial resources be slight. There is a sufficient number of sellers at the retail level, therefore, to provide a basis for effective competition. Moreover, the majors' pressure for gallonage, and in particular their sales of "surplus" gasoline through independent channels, to compete ultimately with their own retailers, help to compress dealer margins. ${ }^{70}$ Except, therefore, in periods when demand outstrips available supplies, competition among dealers apparently keeps the retail spread at a level sufficient merely to pay wages, interest, and a return to the ownermanager little more than sufficient to compensate for the entrepreneurial effort and investment involved. ${ }^{71}$

This does not mean that there have been or are no monopoly elements in dealer margins. First, some dealers doubtless continually earn quasi-rents, increments above the going rates of interest and wages, because of their outstanding abilities or locations. This "monopoly element" is compatible with conditions of extreme competition, and in no way mirrors an inadequate structure or performance of an industry. Second, temporary shortages of gasoline will produce supernormal returns. Retarded construction of new stations during World War II similarly contributed to inflated dealer margins in the years immediately following. These among other factors explain the margins of 6 to 7 cents in northern New Jersey before the 1950 price warmargins generally believed even at the time to have been untenable, particularly in view of the vulnerability of the area to multi-pump operation, and the flow of "surplus" gasoline. In fact, despite the concerted actions of dealer associations, such margins were not maintained.

Third, recognizing their vulnerability to price competition, dealers have made mighty efforts to put a floor under the margin through joint direct action. They have formed associations to enlist the support of the majors and legislatures for state fair trade legislation and municipal ordinances designed to hamper price cutters. ${ }^{72}$ In the New Jersey price wars of 1950

70. This was the basic complaint underlying the Standard of Indiana case, suppra note 1.

71. Thus, according to BaIN, op. cit. supra note 16 , at 233 , dealer margins in California in the 1930's were no more than sufficient to cover costs. Similarly, according to Learned, supra note 17, at 740, any spread in Ohio in 1939 in excess of a "normal" 2 to 2.5 cents proved invariably vulnerable to undercutting by independent dealers. See also Swensrud, supra note 20 , at 8699 . No absolute importance should be attributed to the latter figure; dealer costs vary from period to period and place to place. Professor Taggart found a margin about one cent higher than the above required in Detroit in 1938, to cover costs. Brief of Retail Gasoline Dealers Association of Michigan, Inc, as asisici curize, in Standard Oil Company v. FTC, 71 Sup. Ct. 230 (1951). Average (nominal) dealer margins (based on the posted tank wagon price) in 50 "key" cities in the United States surveyed regularly by the American Petroleum Institute were 5.03 cents on April 1, 1951, The Gasoline Retailer, May 2, 1951, p.3. The survey by Howard, sipra note 3, diselosed a margin of 4 to 5 cents.

72. Included in this category are ordinances banning self-service gasoline stations. Besides many cities, nine states have laws to the same effect. National Petroleum News, 
and 1952, dealers have used extreme pressure (including harassing tactics) against stations that sold at cut rates. As of late 1947 twenty-eight states had in operation laws prohibiting sales below cost: some of these apply specifically to gasoline dealers. ${ }^{73}$ And all but three states have laws authorizing resale price maintenance on trade-marked commodities ${ }^{74}$ however, the usefulness of such statutes is now questionable, due to the Schwegmann decision.75

These measures have failed to prevent price wars. Major suppliers have relieved retailers of the onus of selling below cost by granting concessions in the face of declining retail prices. ${ }^{76}$ Resale price maintenance has not generally been employed, ${ }^{77}$ and where it has there has been little discernible effect. ${ }^{78}$ It is conceivable that these various efforts, many of them belated responses to price wars, may help stabilize retail prices and dealer margins in the future. ${ }^{78}$ Their present influence is apparently small.

August 3, 1949, p. 13. There has never been any proof that self-service stations constitute more of a hazard than those operated by attendants. Ordinances prohibiting "circus signs" are aimed at price cutters. See The Gasoline Retailer, Feb. 7, 1951, p. 9. For examplc, a Connecticut statute enacted in 1951 prohibits the display of price signs except on pumps, and restricts such signs to 126 sq. in. and two per pump. Empire State Petroleum Association, ESPA Weekly Letter, June 8, 1951, p. 3.

73. Mund, Government and Business $453-4$ (1950). Below cost legislation designed specifically to protect retail gasoline dealers: Massachusetts, The Gasoline Retailer, May 10, 1950, p. 3; similar bills introduced in New York and Georgia, id. Mar. 7, 1951, pp. 6, 10; Nevada, Indiana, Ohio, Connecticut, Missouri and New Jersey, id., April 4, 1951, p. $1,3$.

74. MuNd, op. cit. supra note 73 , at 434 .

75. Schwegmann Brothers v. Calvert Distillers Corp., 341 U.S. 384 (1951). Sec Comment, The Schwegmann Case and Fair Trade: An Obituary?, 61 YALE L. J. 381 (1952).

76. See note 82 infra.

77. This has been attributed to the industry's sensitivity to antitrust action. National Petroleum News, Dec. 19, 1945.

78. On the Pacific Coast resale price maintenance extending through the retail price seems to have been generally employed. 1 BaIr, op. cit. supra note 16 , at 203-4. Yet the market was an extremely unstable one during the period (pre-World War II) surveycd by Bain (see note 90 infra). Since 1945 there has been keen price cutting on the Coast, particularly in Los Angeles. On price maintenance in that area, see CASSADY \& JoNEs, op. cit. supra note 38, at 74-5. Ironically, New Jersey, one of the few states whose law in recent years has been used to price fix gasoline, is one of the leading arenas of price wars. See Dressler, Fair Play or Fight (New Jersey Gasoline Retailers Ass'n and Allied Trades, Inc, 1950); Issues Back of the Price Wars, The Gasoline Retailer, Nov. 8, 1950 ; $i d$. June 6,1951, p. 4 ; and Order granting interlocutory injunction, California Oil Co. v. Irving Reingold, C 1721-48 (Superior Ct. of N.J., Bergen County, Aug. 1, 1949).

79. Under the Massachusetts law dealer costs in the Springfield area in a 1951 survey were found to be 5.5 cents, somewhat more than the national average margin at the time. The Gasoline Retailer, Mar. 7, 1951, p. 1. Widespread application of below-cost statutcs, requiring minimum markups in excess of present averages, would surely substantially boost margins and prices. 
Finally, the majors exercise some stabilizing influence on retail prices. Certainly, the unequal financial strength of the parties, the relative wealness of the individual dealer, particularly the dealer who leases his station from a supplier, places the majors in a position generally to discourage retail price competition by pressuring prospective price cutters. And since retail price stability is, within limits, essential to stability and price leadership at the wholesale levels, it is not surprising that pressures of this sort are apparently frequently applied. ${ }^{80}$

However, the influence of the majors does not always keep retail prices high, uniform and stable. On the contrary, certain major suppliers have often exerted pressure on their dealers to reduce prices, although apparently only as a defensive measure to meet price cutters. ${ }^{81}$ This accounts for dealers' objections to companies like Sun and Shell which are known to make a practice of "educating" their dealers to move fast in a price war." The supplier does not usually absorb the entire resultant decline in revenues. ${ }^{83}$

Indeed, there are clear conflicts of interest between suppliers, who would like to to increase their business-at going tank wagon prices, if possible, at discriminatorily lower prices to independent jobbers, if necessary-and retail dealers, who want to be protected against the competition of others enjoying access to supplies at lower than tank wagon prices. Dealers support

80. Our interviews in a rural area in New York State indicated very clearly that in such areas, where traffic is comparatively light, the dealer feels it only safe-as well as good business-to play along with his supplier's "suggested" prices, and that the purpose of these suggestions is to prevent price-cutting. A representative of the Richfield company has recently justified that company's refusal to sell to split-pump operators on the ground that they are often price cutters. National Petroleum News, N1ay 30, 1951, p. 26. See also Cassady \& Jones, op. cit. supra note 38, at 68-79, 92-5, 118; Report of the Governor's Committee to Investigate the Price War, supra note 50, at 6 . This report estimated that 75 to 80 per cent of the service stations are leased from major suppliers. Id. at 8. See also United States v. Standard Oil Co. of Cal., supra note 43, Complaint par. 62, 64.

81. The Independent Petroleun Company, Hcarings before Spccial Committee Investigating Petroleum Resources, 79th Cong., 2d Sess. 369 (1946). See also Swensmd testimony, TNEC Hearings, pt. 15, p. 8699 .

82. See The Gasoline Retailer, January 3, 1951, p. 1 (Sun gives dealers a substantial price reduction): The Gasoline Retailer, Dec. 20, 1950, p.1 (58 service station operators lose suit against Sun for damages from price-cutting, Spencer v. Sun Oil Co. 94 F.Supp. 408 (1950)) ; The Gasoline Retailer, May 16, 1951, p. 1 (Shell blamed for trying to weed out the independents) ; Sun Progress News, for Oil Progress Week, Oetuber 15-21, 1950: "[A] new element has entered the business . . . Their primary appeal is a price conspicuously lower than that of conventional stations. Just this problem was faced this summer by Charlie Hill ... As an old hand, however, dealer Hill knew what to do. Without waiting for the new competition to make inroads on his business, he immediately dropped his price ... Sun Oil Company helped him meet his competition by giving a reduction in its wholesale price to him. Sun helps all its dealers sho are faced by such tratsstal price competition." (Emphasis added).

83. See notes 50,51 supra. 
legislation outlawing below-"cost" sales; suppliers oppose it.84 The majors sell unbranded gas to cut-price outlets; their dealers attack this practice. ${ }^{80}$ Majors may go into multi-pump stations; such developments will obviously take business away from the conventional dealers. Widespread among dealers and jobbers is the opinion that majors engage in direct distribution, or sell through irregular channels, in order to maintain a persistent pressure on margins. Representatives of large companies claim, in any event, that competition from other major suppliers distributing directly is the prime factor compressing the margins of their own distributors.

Thus, the retail margin appears to be very far from a fixed, non-competitive differential. It varies inversely with the strength of the local price-cutterbe he minor marketer, multi-pump branded operator, or branded dealer who gives behind-the-pump discounts. It varies directly with the power of the dealers to prevent defections in their ranks. Most suppliers maintain a position of benevolent neutrality. Because of their investment in stations, and their need for responsible and capable station operators, most major suppliers try to preserve what they believe to be an adequate return to the operator.80 They try to prevent price wars, which endanger their own revenues by driving down the tank wagon price. But there are differences of opinion between suppliers and dealers as to how large a margin is "adequate." And the supplier who manages to conceal discounts longest, attracting trade by secret concessions or by selling through unbranded outlets, makes the most money, until loss of volume moves rivals to retaliation. Such conflicts of opinion and interest are what draw all suppliers, however unwillingly, into price competition.

\section{Conclusions: Evaluation of Gasoline Pricing}

The preceding discussion has attempted to epitomize the nature of gasoline pricing, as well as it can be done by an outsider. The lack of certain important data complicates the task of analyzing, let alone evaluating, the industry's pricing performance. Very little is known about the size or extent of special concessions-other than the regular functional discounts by major suppliers to dealers-special commercial accounts, jobbers and distributors;

84. E.g., a Missouri bill, recently defeated, was sponsored by the Associated Petroleum Retailers of Greater St. Louis, and openly condemned by the Missouri Petroleum Industries Committee. The Gasoline Retailer, June 20, 1951, p. 2A. Similarly, the Ohio Petroleum Industries Committee, the Chairman of Standard Oil Co. (Ohio), and the counsel of the Ohio Petroleum Marketers Ass'n all testified in opposition to an Ohio bill, which died in committee. $I d$. at 6 .

85. Cassady and Jones point out that the aggressive independent marketers who, with their multi-pumps and self-service, have been mainly responsible for the price wars in the Los Angeles area, were supplied in large measure by majors. Op. cit. supra note 38 , at $213-4$.

86. See testimony of Swensrud, TNEC Hearings, pt. 15, pp. 8421-5. The writers' surveys and interviews, supra note 4 , confirm this impression. 
nor is information readily available on the proportion of gasoline in any particular area sold at cut prices, or the proportion of major gasoline sold unbranded. ${ }^{87}$ Likewise, little is known about the extent of discounts given by retail dealers to their customers. All of these concessions, as we have said, may be widespread, at least at particular times and places, yet not be reflected in any posted price. ${ }^{88}$ There is inadequate information to permit generalization about the number and virulence of price wars. ${ }^{59}$

The lack of specific information makes it impossible to reach any clear-cut conclusions about the nature or extent of competition in the gasoline market. In the face of these handicaps, is it possible to choose between the pictures of the industry as sketched by such diverse analysts as Eugene V. Rostow, or George W. Stocking and Myron W. Watkins, on the one hand, and Sidney Swensrud, J. Howard Marshall and other industry spokesmen on the other $: 00$

Any analysis based on published prices is bound to overestimate the degree of price stability in the industry. Bain, for instance, relies on the published

87. Thus, Bain, in writing of the period of stability that prevailed in the Los Angeles market up to the beginning of World War II, discusses the role of third grade, fightingbrand gasolines, but can reach no conclusions about their quantitative importance. Op. cis. supra note 16.

88. Interviews and communications from people in the industry evince belief in the ubiquity of special deals.

89. From the tabulation of tank wagon and service station prices in fifty cities made available each month by the American Petroleum Institute from surveys of The Texas Company, it is sometimes possible to locate price wars from the size of the nominal dealer's margin. See note 93 infra.

90. Is there perhaps a cyclical pattern in commentaries on the oil industry? Writing in 1936 and 1937, Irene Till saw the pricing of gasoline as intensely competitive: the central problem of the market was to introduce some measure of stability. See Hasuruton, op. cit. supra note 40, at 117, 191-9. Likewise A. K. Burns, with the 1930-1933 experience, when mid-continent crude sold below $\$ .50$ a barrel, fresh in mind, really emphasized the rise of competition in the gasoline market rather than the contrary, and leaves the general impression that price leadership has not had a significant effect on the course of prices. Op. cit. supra note 16, at 99-103. Bain, limiting himself to the Pacific marlet prior to World War II, and scrupulously careful in his conclusion not to go beyond the generalization that the industry never achieved more than a precarious equilibrium, shows that stability-such as it was-was attainable only through outright collusion and through buying up "distress" gasoline of minors. 1 Bam, op. cit. supra note 16, at 203-5; 2 id. at $285-90$.

In contrast, Rostow, writing during a period of inflation, when the memory of price wars had faded, places in the foreground the theory of price leadership, using to buttress it descriptions of prorationing and the attempt of the midwest marketers in 1935 to prevent hot oil and distress gasoline from brealsing the tank car price. The brief comments on the industry by Stocking and Watkins are confined, similarly, to the monopolistic character and consequences of price leadership and prorationing. STocrsmo \& WATris:s, Modofoly AND FREE ENTERPRise 50n., 132-3, 389-92 (1951).

This thesis (of cyclical fluctuations in cumments on the oil industry) may easily be exaggerated. The points of view of the Department of Justice, on the one hand, and of industry spokesmen, on the other, have shown no such variability. 
tank wagon prices from Platt's Oilgram in concluding that the period 19371940 was one of stability in the Los Angeles market. ${ }^{91}$ Rostow does the same. If very few transactions actually take place at these prices, generalizations based on their height or stability are not very useful. If price wars enter our calculations only when they are reflected in changes in posted retail (let alone posted tank wagon) prices, we are bound again to err in our judgments. The posted retail price in New York, for example, is said to conceal extensive price-cutting. ${ }^{92}$ The indication of a price war today (in the absence of more direct information from the scene) is to be found characteristically in the shrinkage of the nominal dealer's margin based on the posted tank wagon price. ${ }^{93} \mathrm{We}$ do know that these forms of price competition are important, and that gasoline prices at all levels are frequently lower and less stable than is supposed by leading critics of the industry; we do not know how important these deviations are.

Deductions drawn from the mere fact that a certain company is called the "market leader" or "reference seller" can likewise be carried too far. Leaders do not in many cases actually lead. The market often gets away from them on the downward side; in these cases it is usually minor marketers or other majors' marketers who render posted prices more and more fictional and force the leaders to follow, first in a discriminatory fashion, later openly. There have been numerous instances of this sequence of events-in the 1920's, 1930's and 1950's. ${ }^{94}$ Moreover, there are certain majors, notably Sun Oil Company, which never can be counted on with complete assurance to follow price increases. In the same category of price shaders or unreliable followers are "minor majors," or majors trying to break into a new market. The writers have encountered frequent reports that some oil companies, in some areas, may shade the posted price of the leader, in order to obtain additional business, or to compensate for somewhat less consumer acceptance of the brand. ${ }^{.5}$ Other reports note lags and leads in the follow-the-leader pattern, perhaps because the follower disagrees with the leader's implied appraisal of market conditions, or feels his own costs do not permit him to follow at once, perhaps

91. 2 BAIN, op. cit. supra note 16 , at 207-8.

92. A bulletin of the Inter City Gasoline Dealers Association complains of the widespread use of "coupons, discount cards, punch cards, stickers, stamps, throw-aways, and who knows what else. All now rapidly rotting out, tearing down and giving away your profit. . ." 200,000 members of the New York Automobile Club, it complains, are "getting $40 \%$ of the dealers' profits." The Gasoline Retailer, May 16, 1951, p. 4.

93. See, e.g., tables showing tank wagon price and dealer's posted price in 50 citics, in The Gasoline Retailer, Jan. 3, 1951, p. 3, and comment. In Portland, Me., the (nominal) dealer margin, based on the posted price, was $\$ .001$. Dealers can hardly continue price wars for very long without discounts from their suppliers.

94. See, e.g., BurNs, op. cit. supra note 16, at 97-100 and the discussion of recent price wars, above.

95. See, e.g., TNEC Hecrings, pt. 15, pp. 8437-52; The Gasoline Retailer, May 10, 1950. 
even in order to avoid the accusation of collusion on prices. Finally, there have been price wars, at the retail level, into which the major companies have been drawn.

Hence, the general practice of price leadership is not in itself sufticient to demonstrate that the industry is actually functioning like the hypothetical self-disciplined oligopoly hypothetically sketched at one point earlier in these pages. The historical convolutions of Standard of Indiana's pricing policies, described above, indicate clearly that leadership was in no way able to freeze prices against changing market conditions in its area. The same conclusion seems warranted from the fact that Eastern wholesale gasoline prices were ranked above the average in their sensitivity to the 1929-37 repression, and in the highest of ten commodity groups with respect to the frequency of their changes in the period 1926-33.96

On the other hand, these various forces of price competition appear, understandably enough, to operate most effectively when surplus supplies are "looking for a home." Without outright collusion, and programs for buying up homeless gasoline, excess supplies can apparently not be prevented from spoiling the market. Thus it is not surprising that gasoline prices ranked high in depression sensitivity and variability in the period 1926-33, when crude output suddenly and unpredictably soared, and controls were as yet weak.

To the extent "orderly conditions" prevail, a general policy of price leadership does permit relatively stable, quasi-monopolistic pricing. For example, in rural areas where there is little prospect of attracting gallonage by a price cut, and where no new marketer is trying to enter the field, minors maintain a stable differential and majors and their marketers present a dignified and gentlemanly quiescence on the price front-even when price wars abound elsewhere..$^{97}$ In short, the "intense competition," to which industry representatives so frequently allude, is, as we have seen, apparently of a limited, peripheral, exceptional character. The tank wagon price and the price to the consumer are insulated against it, in so far as possible. The leader does not always lead, the posted price is often fictional, and sometimes breaks down in particular areas. ${ }^{88}$

96. 1 National fesources Counsittee, The Structure of the Asrerican Eco:io:sy 193 (1939-40). It appears that refining and marketing margins were somewhat less sensitive to the depression, though not less variable: crude oil prices (in Kansas and Pennsylvania, but not in California) showed a higher depression sensitivity (but a lesser frequency of price change) than (refined) gasoline Ibid.

97. The price of Socony-Vacuum, the leader in New York State, changed only four times in 1950. Eurpire State Petroleum Association Directory 45 (1950). See also Howard surveys, supra note 4. And while in price war areas the posted price is fictional, in other areas there is good reason to think that for the great bulk of transactions it is not.

98. Thus the New Jersey Committee, under the supervision of Waiter T. Margetts, Jr., State Treasurer, appointed to study the price war, concluded that "under 'normal' 
The role of governmental control of output by prorationing reduces the possibility of supply getting out of control. Just as the independent refiners and jobbers, who are most apt to be the price shaders, thrived on the cheap hot oil of the early 1930's, so their ability to disrupt the market has undoubtedly been diminished by prorationing. ${ }^{00}$

The absence of price wars and even control of crude production does not prove that the consumer is being exploited. Despite prorationing and price leadership, profits in the industry as a whole do not appear to have exceeded the average for all manufacturing in the last twenty years. This fact may be attributable to the limited success if not breakdown of price leadership and market controls in the 1930's, to government price control during the war, and, in part, to self-restraint in recent years-a familiar tendency, not confined to this industry. Nor is such restraint merely a manifestation of noblesse oblige. There appears in addition to be sufficient divergence of interest and point of view among major companies, and sufficient independent

conditions ... the general retail price levels of graded and branded gasoline are somewhat artificial in nature . . . governed more by mutual understanding . . than by cconomic factors." Price wars were regarded as abrupt collapses, under strain, of this artificial structure. Report of the Gasoline Study Committee 4 (June 14, 1951). The Connecticut investigation committee (supra note 50 , at 2 ) reached an almost identical conclusion, althought somewhat more tentatively.

99. The majors contend that the refiners who sprang up were only topping, or "teakettle" operators, who could have no permanent place in the industry. However, a comparison of Roy Cook's indictment of the major oil companies and the reply to him brings out the following area of agreement: that the cheap and plentiful crude oil in East Texas in the early thirties induced a great expansion of independent refining capacity; and that the subsequent rise in price of crude narrowed the refining margin and contributed to a marked decline in independent refining capacity in that particular area. In addition, the reply to Cook did not dispute his figures demonstrating that independent refiners operate at a far lower percentage of capacity than majors, and that this disparity was far greater in 1937 (after production control) than in 1926. Cook contends that this disparity was attributable (in part?) to the formers' greater difficulty in obtaining crude, the result, among other things, of production control. The reply does deny that the independent refiner either has been declining in relative importance or is placed by prorationing or by majors' control of pipe lines at any greater handicap than majors in obtaining crude. Cook, op. cit. supra note 23 , at 14, 32-4; REviEw aNd CruTICISMs, op. cit. supra note 23, at 21-4, 39-42, 85-6.

In the period of severe crude oil shortage, in 1947, independent refiners again operated at a far lower percentage of capacity than majors, and there was a good deal of evidenco that inferior ability to command supplies of crude was responsible. See OnL SuppLY AND Distribution Problems, op. cit. supra note 40, at 9, which contends that "the independent refiner is rapidly disappearing from the oil industry as a competitive factor." The report bases this contention only on the 1946-47 experience. It is undeniable, at least, that many independents find it either advantageous in terms of price or mandatory under crude processing agreements to sell their refined products to the major oil companics.

The South Carolina Oil Jobbers Ass'n has opposed the Interstate Oil Compact, on the ground that it prevents them from securing adequate supplies during tight periods. National Petroleum News, June 20, 1951, p. 38. 
refining capacity ${ }^{100}$ to limit the ability of the leaders to carry prices much higher than they have been in recent years. Gasoline "leaders" could not. for example, have imitated the "Big 3" cigarette manufacturers, who under a price leadership formula were able to raise their prices above 1929 levels in 1931, and earn profits of over $\$ 100$ million in $1932 !^{101}$

The economic performance of an oligopolistic industry might be deficient in other ways than reaping exploitative profits: costs might be higher, or the industry less progressive than under some alternative system. ${ }^{102}$ While the majors have not and could not reasonably be charged with technological backwardness, in view of the genuine rivalry among them in this respect, ${ }^{103}$ there is some reason to believe that they are using resources uneconomically in retailing. ${ }^{104}$ The profusion of service stations is certainly a product more of competition for market coverage and gallonage than of restraints on supply in the interest of monopoly profits, ${ }^{105}$ but it may none the less be wasteful.

The pattern of competition in constructing, and encouraging the construction of new, exclusive service stations, blanketing every possible market, is a consequence in large measure of the structure and policies of the majors.

100. There are apparently numerous independent refiners, mainly in the Gulf Coast area, who open up and shut down depending on the size of the margin. See The Oil and Gas Journal, August 11, 1949, p. 120; id. November 17, 1949, p.119. The "squeeze" on East Texas independent refiners alluded to above, when the price of crude rose relative to that of refined products, is also in point. A reversal of the squeeze, produced by a higher price of gasoline, would presumably induce their return. See id., August 17, 1950, p. 154, for instance of reopening of a Gulf refinery (Sidney Richardson).

101. American Tobacco Co. v. United States, 328 U.S. 781 (1946).

102. It has been pointed out that a refusal by oligopolists to exploit possibilities of price increases in inflationary periods may result in a distorted pattern of resource use, by discouraging an economically desirable expansion of capacity. See Adams, The Stcel Industry in The Structure of American Industry 190-2 (1950). However, in the absence of either supernormal profits or the necessity for rationing end products, there is no convincing evidence that the economy would have benefited from higher petroleum prices and profits.

103. This is not to ignore numerous specific allegations of retardation resulting from the patent position and market tactics of individual companies, in individual productslike synthetic rubber, and pour point depressants. It would carry us too far afield, in a discussion of the pricing of gasoline, to evaluate these many charges.

104. We set aside, as not directly relevant to an evaluation of the pricing of gasoline, the question whether the undoubted restraint on the output of crude oil, for which the oligopolistic character of refining is not mainly responsible, represents an underutilization of natural resources. See note 39 supra. The mixture of purposes in current prorationing practice is clearly brought out in $A$ Primer on Proration and Oil Consercalion as Procticed in Texas, address by Ernest O. Thompson, July 25, 1946; The Applieotion of the Market Demand Statute to Oil Production in Texas, address by Ernest O. Thompson, Feb. 14, 1950.

105. Of course, monopoly pricing may itself be the cause of excess capacity, by attracting an excessive number of new entrants. It seems unlikely however that monopolistically high profits in retailing account for the possible excess of service stations. 
It is not possible definitively to resolve the question whether the better and quicker service which motorists enjoy because of this profusion of stations compensates for the higher cost of a capacity which is physically idle a good deal of the time. The point is, however, that the consumer is not in most areas given the opportunity to choose. ${ }^{106}$ In food retailing the chain and self-service super market, on the one hand, and the corner grocery, on the other, offer the buyer a choice between price and service (personal attendance, location within walking distance, credit, etc.). In gasoline, a major cannot readily offer both alternatives-numerous, conveniently situated stations, and large-volume low-markup multi-pumps-and keep all of its dealers contented. Whatever the reason, most of the integrated firms offer only the former. It has been the independents who have pioneered, since the war, in multi-pump and partial self-service stations, at lower prices; and they have, with increasing customer price-consciousness, in many places taken away so much business as to have been the prime instigators of price wars. ${ }^{107}$ Additional evidence that this choice of retailing policy by the majors may have been wasteful is implied by the fact that returns in marketing-by such limited and extremely arbitrary accounting measures as are available-seem to have run consistently lower than in other branches of the industry during the last twenty years. ${ }^{108}$

The economic performance of an industry must meet other tests than the purely economic ones thus far employed. Have the pricing policies of the major marketers been fair to independent refiners and distributors? This query raises broad and fundamental questions, to which there is no simple, scientific answer, about the proper definition of fairness of competition, and about the compatibility of tests of equity with "economic" criteria. ${ }^{100}$ It is clear, however, that where suppliers compete with their customers, either

106. See Leon Henderson, TNEC Hearings, pt. 15, pp. 8417-8.

107. See WollstadT, op. cit. supra note 48; CASSADY \& JoNEs, op. cit. supra note 38.

108. Eleven integrated companies attempted to classify their income and assets among the four major operations, production, transportation, refining and marketing, for cach of the years 1936-38. Comparisons of these estimates reveal a rate of return on total assets in marketing lower than in production in 29 out of 30 cases, lower than in transportation in 33 out of 33 cases, lower than in refining in 22 out of 33 cases. TNEC Hearings, pt. 17-A, pp. 10039-42. Of the thirty leading oil companies studied annually by the Chase National Bank, the nine engaged solely in production earned an average of $8.8 \%$ on invested capital in the nine years 1934-42, and the four integrated majors who produced more crude than they refined (and presumably marketed) earned $8.2 \%$, compared with a return of $6.2 \%$ for the 17 who refined (and presumably marketed) more than they produced. Pogue \& Coqueron, Sources, Disposition, and Characteristics of the Capitat, Employed by Thirty Oil Companies During the Nine-Year Period 1934-42 20 (Chase National Bank, Feb. 1944). The discrepancy shown in the same authors' study for 1944 (published Nov. 1945, at 23) is even more striking. Their subsequent annual studies make no such comparisons.

109. These problems are analyzed in detail in Dirlam \& Kahn, Price Discrimination in Law and Economics, 11 AM. J. EcoN. \& Soc. 281 (1952), and, in a specific instance, in Dirlam \& Kahn, The Antitrust Laws and the Big Buyer: Another Look at the $A$ of $P$ Case, 60 J. PoI Econ. 118 (1952). 
directly, as the majors do for commercial customers with their jobbers, or indirectly, by selling at cut prices branded or unbranded gasoline which is then marketed in competition with the regular dealers, it is possible for an unfairly discriminatory price structure to be built up. Deprived of direct control over retail margins, the majors may (as has been clained in the Standard of Indiana case) ${ }^{110}$ resort to favoring price cutters in an effort to bring down margins. Whatever the intent, the effect of this sort of discriminatory price competition may be to threaten the existence of distributors whose only economic deficiency is in bargaining power. Most dealers are not in a position to bargain for a better price. If they are ground between a fixed tank wagon price and the competition of independent marketers to whom the majors have made truly discriminatory concessions, there is some reason in the argument that the particular limited form of competition chosen by the majors is unfair in its effects, whatever its purpose. ${ }^{111}$

Where there are monopoly elements at one horizontal stage in an industry, the vertically integrated firms whose operations encompass one of these stages undoubtedly enjoy competitive advantages over the non-integratedadvantages, again, which are clearly strategic, and not necessarily related to efficiency. Certainly the integrated oil companies have enjoyed such advantages over unintegrated refiners and marketers, in the shape of higher returns in production and transportation, and superior access to crude in times of shortage. And certainly their competition in marketing has in effect been "subsidized" by their quasi-monopoly profits at other levels. ${ }^{112}$

But proceedings involving discrimination, as we are only too unhappily conscious from the Standard Oil of Indiana, Spark Plug, and $A \& P$ cases, can be extremely costly, needlessly devious and complex, and irritatingly unrealistic. ${ }^{113}$ Absolute principles are marshaled on both sides when what is involved is a conflict of values and interests that must, in the end, be compromised in a workable fashion. In the Standard of Indiana case, the public interest demands a retail margin that is not too high; perhaps Ned's can do the job at a lower margin than most retailers, but then other retailers who can offer Standard the same cost savings in delivery should be permitted to buy at a price equal to Ned's. What is needed is a tribunal-and not necessarily a governmental one-before which these issues can be brought into the open. In view of the doctrinaire position being taken by the F.T.C.

110. See Brief of Retail Gasoline Dealers Ass'n of Mfichigan, supra note 71.

111. See Report of the Governor's Committee to Investigate the Price War, supro note 50 , at p. 4 .

112. See note 108 supra; also Watkms, op. cit. sutpra note 40, at 186-7; Cook, supra note 23, passin. Cf. Adelman, Integration and Autitrust Policy, 63 HARv. L. REv. 27, 41-3, 53 et seq. (1949). One of the present authors discusses criteria of uniairness applicable to integration in a manuscript on "The New Criticism of Antitrust," in preparation.

113. These problems and cases are discussed in detail in Dirlam \& Kihn, Price Discrinatination in Law and Economics, supra note 109. Cf. Rowe, Priec Discrimisalion, Competitson, and Confusion: Another Look at Robinson-Fatman, 60 YALE L J. 929 (1951). 
in recent price discrimination cases, it is not clear that the Commission has the perspective to strike an acceptable balance between the conflicting interests and at the same time to recognize the paramount interest of the consumer. Certainly its insistence that jobbers be denied discounts on the basis of the function they perform goes too far in sacrificing the consumer in the interest of the non-integrated retailer. ${ }^{114}$

\section{Vertical Dissolution as a Fundamental Reform}

Critics of the industry have urged that some more fundamental solution, like thoroughgoing vertical dissolution of the majors, ${ }^{116}$ is required in order

114. Compare the judicious opinions of Judge Smith in dismissing the complaint of 58 Meriden, Conn., dealers, who would have denied Sun the right to help its dealers mect price cutting (Spencer v. Sun Oil, supra note 82), and of the Report of the Gasoline Study Committee in New Jersey, supra note 98 . One factor in'the Spencer case was that most of the plaintiffs had been offered similar concessions from the tank wagon price by their suppliers-indeed four of them were Sun dealers-and had jointly agreed to reject the discounts and to maintain retail prices. On the other hand, it is not clear that the law has offered adequate redress to the plaintiffs in the Myers suit (supra note 46), which was thrown out mainly because the discriminatory transactions involved were held not in interstate commerce. The complaint in this suit is summarized in Howard, The Markcting of Petroleum Products, supra note 4, at 140-3.

115. This proposal is one of Rostow's two fundamental solutions for the industry, op. cit. supra note 16, at 144 , and is embodied in S. 571,572 and 573 , introduced in the 81st Congress by Senator Gillette.

While probably most jobbers and dealers would oppose any attempt of the government to dissolve the majors, and criticize people like Professor Rostow for failing to perceive how competitive the oil industry really is, it seems quite clear also that thoy would be very happy to have the majors abstain voluntarily from invading their territories (defined both functionally and geographically). Thus Mr. Warren Platt, editor of the National Petroleum News, recently condemned the practice of major oil companies of buying out independent jobbers, on the ground that this would diminish the amount of competition in the industry. National Petroleum News, May 9, 1951, p. 23: "NPN does think the majors highly foolish, especially these days of rough political and judicial going, in eliminating competition by such purchases when in the majority of cases the major could arrange that the competition is continued and the would-be-buying major could continue to enjoy the gallonage the jobber represents." See the editorial offering the CocaCola Company's "Business 'Empire' Run by Independents" as a model for major oil companies. Id., May 23, 1951, pp. 25-6. Indeed, recent statements by officials of jobber and dealer associations are composed of an interesting mixture of protest-against "dirty" competition by majors, entreaty-for more respect for their interests (an end to undercutting or bypassing them, a plea for better margins) -and threat-that their willingness to defend the status quo against a meddling government depends on a favorable response to their protests. "Tennessee jobbers have launched a program to give suppliers a chance to correct unfair margins before the Independents take their troubles to the Government." National Petroleum News, May 30, 1951, p. 30; "The suppliers need the jobbers and in the not-too-distant future, the suppliers may be seeking a showing of good faith from the jobbers. Where could they find a better advocate before a congressional committee than a group of independent jobbers ready and willing to testify that they oppose divorcement." The Gasoline Retailer, May 16, 1951, p. 32. 
to eliminate the market power and unfair competitive advantages of the big, integrated companies, and thus achieve both goals: restoration of freer price competition (hence an improved economic performance) and equity for the small and non-integrated. It seems doubtful that such a remedy, any more than a doctrinaire attitude toward rules governing competitive practices, would ensure a superior economic performance. First, extensive interviews and perusal of the trade literature confirm the impression that individual jobbers and retailers would continue voluntarily to tie themselves to one major supplier. Supply is their crucial problem.110 Only a small minority seem willing to seek the advantages of "shopping around" (although in periods of declining demand they have been more inclined to do so) at the risk of losing the assurance of continued supply of a nationally advertised brand, with a more or less secure patronage and margin. ${ }^{117}$ It would appear to be impossible in time of shortage to prohibit large refiners taking care first of their best and steadiest customers.

Thus where major companies today deal through regular distribution channels, they would probably continue to do so. Competition in the industry today arises largely out of the situations in which they by-pass these channels. And it is these situations of dual operation and direct distribution which vertical disintegration would prohibit. Were the majors divorced from bull: marketing, the independent jobbers, relieved of this efficient competition, might well succeed in raising margins. ${ }^{118}$ It seems likely that, judging by the cost-saving progress of the majors, a multiplicity of jobbers would impose higher costs on the distribution system. The removal of the direct competition of majors would undoubtedly remove a force now exerting a continuous downward pressure on these margins and bringing lower prices to the consumer. ${ }^{119}$

116. Oll Industry and Distribution Problears, op. cit. stpra note 40, fassims. The point was given primary emphasis by distributors interviewed by the authors and Howard.

117. See Howard, Survey of Petrolcun Jobbers in Central New Yorl, sufra note 4, at 6. This prediction in no way vitiates the contention of the Department of Justice, sustained in the Standard of California and Richficld cases (supra note 1) that dealers ought to be free to handle more than one brand if they so desire.

118. A glance at the trade journals indicates that they will surely try. On the downward pressure of direct major distribution on jobber margins, see p. 842 supro. We cannot assess the adequacy of existing margins. It seems to be true, however, that oil jobbers seldom fail. It is also of interest that their attacks on current levels of margins are invariably in terms of a comparison of the cents per gallon with a change in cost indexes or prices-never in terms of return on the jobber's investment. See, c.g., the survey by the South Carolina Oil Jobbers Assn., National Petroleum News, June 20, 1951, pp. 35, 38; and the editorial, paradoxically in the same issue (p. 31), pointing out the decline in jobber costs per gallon over the years, because of the great increase in volume of sales.

119. Professor Watkins' interpretation of the marketing provisions of the N.R.A. code seems in conflict with this point of view: "In its ultimate significance ... the discipline invoked by the multifarious provisions of Article $\mathrm{V}$ of the code was in the nature 
It is precisely the present pattern of mixed operations, with majors at one and the same time dealing through regular channels, selling direct, and dealing with independents, which creates the conflicts of interest and makes the industry's pricing as competitive as it is. ${ }^{120}$ According to the dealers and jobbers it is the majors who "stir up trouble," or who could at least stop it if they wished. A vertically integrated firm has always before it the final consumer, and the incentive to keep the price low in order to preserve that customer's good will. A vertically disintegrated industry, each segment protected against encroachment from above or below, is far more concerned with adequacy of margins and interstitial markups. ${ }^{\mathbf{1 2 1}}$

of preparation for the extension of financial hegemony over a field in which high finance had not previously found it feasible to push very far, owing to the stubborn independence and artless insubordination of the tens of thousands of small businessmen there engaged." Op. cit. supra note 40 , at 173 . There is no disposition here to quarrel with the contention that the majors were anxious to establish more "orderly" (less competitive) marketing, through the Code. But the implication that the majors are the persevering stabilizers, and the independent marketers the incorrigible upsetters of the stable price seems overdrawn. The competition which the majors sought to suppress by these elaborate marketing controls was competition among themselves: it was their price concessions and indirect price competition in large measure which made it possible for the jobbers to upset the market. Only after proscribing these unstabilizing influences (and of course eliminating other cheap gasoline supplies to jobbers, by prorationing and buying up independent gasoline) would seeking to secure fixed jobber and retail margins have meaning.

Moreover, as Professor Watkins points out, the majors made not even "an earnest endeavor" to apply Rule 6, which stipulated that integrated companies should attempt to equalize their rates of profit in different strata. Instead, they persisted in securing as maly market outlets as possible, subsidizing their heavy competitive pressure in that area by higher profits elsewhere. WatKINS op. cit. supra note 40, at 186-7.

We do not contend that either major suppliers or distributors are as a group more prone than the other to "self-government in industry." The point is that a rigid segregation of each group in its respective field will further protect these anticompetitive tendencies from disruption from without, and thus increase the likelihood of fixed margins, and rigid, non-competitive pricing such as the N.R.A. codes sought to establish.

120. It is understandable that jobbers urge the majors to keep out of the distribution field. The five point program for majors proposed by Mr. John Harper, then Vice Chairman of the National Oik Jobbers Council, was in effect a program for limiting the competition of major oil companies with their distributors. Its first two points were: "1. Market a large portion through jobbers and distributors in each territory. 2. Sec that jobbers and distributors do not go out of business." National Petroleum News, July 26, 1950, p. 38. The viewpoint of the distributors appears equally plainly in an editorial by Harry Hilts: "The problem of non-cooperation among the various elements of the industry probably stems from the dual nature of the competition faced by each segment. Competition is severe along the horizontal level, but it is also severe between the horizontal and vertical components. When a marketer not only has to compete for business with a fellow markteer, but also with his supplier, tempers are apt to get ragged." Empire State Petroleum Ass'n News, July, 1951, p. 3.

121. This argument, expressed in business terms by J. Howard Pew, in Review AND CRITICrSms, op. cit. supra note 23, at 13, is given a more precise formulation by Spengler, Vertical Integration and Antitrust Policy, 58 I. PoL. EcoN. 347 (1950). It is not by any 
The case for integration of marketing and retailing is less strong. It was a partial separation of the two functions as a result of the Iowa Plan (under which refiners turned over operation of their filling stations to lessees or independent owners) which drove a wedge of interest between suppliers and their dealers. Prior to 1936 , it would have been less to the majors' interest to compete with their own retail outlets by making sales to special outlets at cut prices. ${ }^{122}$ Dealers, like jobbers, have amply demonstrated their desire for a stable margin and have attempted to secure it, not only through pressures for protective legislation, but also through the development of an anti-competitive esprit de corps among themselves (like that of barbers, bakers, plumbers, and other small businessmen ).123

It seems therefore that were the majors to relinquish all financial interest in their stations they might be even more willing to sell to price cutters who compete with their present retail outlets. Our defense of dual operations by the majors does not extend to their retailing. Their direct retail operations have not been a significant source of aggressive price competition; on the contrary, the outlets which they have themselves operated have usually been the most reluctant to lower the price umbrella, and have done so only when forced by independent price cutting. ${ }^{124}$ And their dual role as landlord and supplier has undoubtedly enhanced their ability to "suggest" (stable) retail prices to their dealers. ${ }^{125}$ Were refiners to withdraw as landlords, they would have less incentive and less power to maintain the retail margins, in the interest of their (exclusive) dealers and the sheltered tank wagon price. This change might make it easier for aggressive, large volume retailers to introduce the same kinds of innovations as have revolutionized grocery retailing. Moreover, the withdrawal of the majors from financing the competitive multiplication of outlets might also diminish the major apparent source of waste in the industry.

means dependent on physical or engineering savings associated with large-seale production, or continuous processing. The superior efficiency of the vertically integrated firm may be associated more closely with incentives to develop new and cheaper methods in those parts of its operations which are, for the moment, strategic bottlencelss.

122. "The whole trouble ... stems from the fact that for the past 15 years there has been no firm price making in the industry. $U_{p}$ to the middle thirties, the suppliers themselves controlled a sufficiently large percentage of their retail wutlets to set the price pattern." The Gasoline Retailer, June 6, 1951, p. 4.

123. The following quotation illustrates the point of view of the small retailer-and let the reader ask himself whether this is not more characteristic of the numerous dealers than of the few large suppliers, when the few includes Sun Oil Co.: "It is disgraceiul when there are some people who offer the customer no reason for buying their merchandise except low prices." The Gasoline Retailer, April 18, 1951, p. 2A. See generally, Marl:ham, The Effectiveness of the Antitrust Laiis, 40 AMEr. ECoN. REv. 167 (1950).

124. Learned, sipra note 17 , at 731,744 and passim.

125. Any supplier who makes it a practice to offer dealers a discaunt to meet lueal price competition would presumably still have an incentive to du so, even though no longer a landlord. 
However, it would probably be inadvisable even in the case of retailing to issue a blanket prohibition of vertical integration. If majors wish to own and operate certain stations, as demonstration outlets, or yardsticks, or in order to experiment with new forms of retailing, effective competition probably requires that they be permitted to do so. Thus any general, hard-and-fast application of vertical divestiture would probably create no improvement over the present marketing structure and practices prevailing in the industry.

These conclusions in no way minimize the role of antitrust policy in the oil industry. It is fashionable to deprecate the contribution of the antitrust laws to the economy; yet how much more monopolistic would be the structure and pricing policies of the petroleum industry today had we no such legislation or were enforcement less aggressive? There will always remain problems of preserving some rough equity in pricing practices, and preserving and increasing competition. Concerted buying programs and systematic price leadership ${ }^{126}$ should always be attacked as and if they appear. The same is true of any evidences of squeezing independents-by depriving them of crude oil, or of access on substantially equal terms to transportation facilities, market outlets (through enforcement of exclusive dealing) and refined products. Workable procedures in government and in industry itself must be developed to reconcile the sometimes conflicting dictates of competitive flexibility and the right to "meet competition" by discriminatory pricing or by exerting pressures on dealers, on the one hand, and fair access (on equal terms) to supplies and market outlets, on the other. Finally, the balance between the dictates of conservation in production and competition in the industry as a whole must be improved so as to reduce not only the competitive advantage conferred by production control on the integrated firms, but the exploitation of consumers for private gain which it also entails.

In individual instances, the present organization of the inclustry may be too tight, too compact for adequate, or reasonably fair, competition. In these instances, antitrust decrees enforcing some reorganization (such as divestiture of service stations, pipe lines, prohibition of dual operations, etc.) of the companies involved may be required to introduce greater flexibility and opportunity for independents. Such remedies may correctly include vertical dissolution, or a prohibition of vertical controls-provided they do not impose a complete stratification upon the industry, which prohibits the kind of competition that arises when a frm in one horizontal stratum extends its activities into another.

The most important economic advantages of vertical integration are to be found in its dynamic aspect: the contribution that an oil refiner makes when he sets up an exploration and drilling division, or breaks into marketing in competition with established distributors or into petrochemicals in competition with established chemical companies. The far superior (static) efficiency

126. As in the American Tobacco case, supra note 101. 
of compact vertical organization, so often claimed by industry spokesmen, has never been satisfactorily demonstrated.

An alternative reform, which might be desirable in individual cases, is horizontal dissolution. By creating a larger number of still vertically-integrated, yet smaller, firms in a given market area, such divestiture might reduce excessive market power, without sacrificing the dynamic contribution of vertical integration. ${ }^{127}$

The accomplishment of these antitrust tasks calls for constant surveillance and judicious balancing of conflicting interests and goals. It is difficult to conclude, from the foregoing survey of the pricing of gasoline that any simple, fundamental correctives are necessary or could hope to achieve success in improving the performance of the industry.

127. However, it must be recognized that the effect of creating a larger number of integrated firms, each with smaller capacity and marketing facilities, cannot be predicted with any assurance. The number of competitors in any particular area might not at the outset be changed, dissolution having the effect merely of severing the financial linlss between geographically separate refineries and bulk distribution facilities. On the other hand, the drive of these smaller units to expand might, if mergers were forbidden, lead to invasion of each others' markets and a greater number of competitors in each than is typical today. The growth of competition after the dissolution of the Standard Oil Company in 1911 was certainly attributable in part to the ensuing marlset interpenetration (by vertical integration and geographic expansion) by the successor companies. 